\title{
Kinetic Study of the Partial Hydrogenation of 1-Heptyne over Ni and Pd Supported on Alumina
}

\author{
M. Juliana Maccarrone, Gerardo C. Torres, Cecilia Lederhos, Carolina Betti, \\ Juan M. Badano, Mónica Quiroga and Juan Yori
}

Additional information is available at the end of the chapter

http://dx.doi.org/10.5772/48699

\section{Introduction}

Selective hydrogenation reactions are industrially used for the partial hydrogenation of unsaturated organic compounds in order to form more stable products or intermediate materials for different processes. The production of final organic products of high added value or intermediate compounds for the synthesis of fine chemicals is both of industrial and academic importance [1]. Alkenes are much appreciated products used in the food industry (flavours), the pharmaceutical industry (sedatives, anesthetises, vitamins) and in the perfumes industry (fragrances). They are also used for the production of biologically active compounds [2], resins, polymers and lubricants, etc.

The partial hydrogenation of acetylenic compounds using homogeneous or heterogeneous metallic catalysts provides a very viable and economically feasible way for the obtaining of these olefinic compounds. Selective catalysts and optimum operational conditions are necessary in order to avoid the complete hydrogenation of the unsaturated bond. Certain transition metals anchored on different solids have demonstrated to be very active and selective catalysts for this type of reaction. They also have the advantage that they can be operated under milder reaction conditions. It is well documented that palladium is a highly active catalyst for hydrogenation [3]. In this sense, Lindlar catalyst $\left(\mathrm{Pd} / \mathrm{CaCO}_{3}, 5 \mathrm{wt} \%\right.$ of $\mathrm{Pd}$ modified with $\mathrm{Pb}(\mathrm{OAc})_{2}$ ) has been used since 1952 as an excellent commercial catalyst for this type of reactions [4]. The argued reasons for the differences in reactivity of $\mathrm{Pd}$ indicate that when the metal is electron deficient it becomes less active because alkynes are more weakly adsorbed [5].

During decades a lot of research has been carried out modifying this type of catalysts in order to increase the activity and selectivity: different supports as alumina, coal, silica [5-7] have been tried while modified palladium [8], or nanoparticles of $\mathrm{Pd}$ have also been 
investigated [9-11]. In a recent work of our group very high activities and selectivities of W monometallic and W-Pd bimetallic catalysts were found during the partial hydrogenation of a long chain terminal alkyne [12]. In this contribution it was reported that important variations in the activity and selectivity were produced when the employed pretreatment conditions were changed. The published reports do not give a clear explanation of the effect of each metal.

Providing an economic, active and selective metallic catalyst for the production of alkenes via selective hydrogenation is a very important challenge. Besides the bibliography on the kinetics of the reaction of heavy alkynes is scarce [13-15]. In this sense, the kinetic study of the liquid phase hydrogenation reaction of 1-heptyne using monometallic nickel and palladium catalysts anchored on $\gamma$-alumina made in the current work had three principal objectives: i) to gain knowledge about the reaction system, ii) to obtain kinetic expressions which enable the design of partial hydrogenation reactors, and iii) to give an explanation of the catalytic effect of different metals. The kinetic modelling was used in this work to shed light on these issues.

\section{Experimental}

\subsection{Catalyst preparation}

The catalysts were prepared by the incipient wetness technique using Ketjen CK300 $\gamma-\mathrm{Al}_{2} \mathrm{O}_{3}$ as support (cylinders of $1.5 \mathrm{~mm}$, calcined at $823 \mathrm{~K}$ during $4 \mathrm{~h}, 180 \mathrm{~m}^{2} \mathrm{~g}^{-1}$ BET surface area). To study the influence of metals, acidic solutions with $\mathrm{pH}=1$ were prepared using $\mathrm{NiCl}_{2}$ (Merk Cat. No. 806722), and $\mathrm{Pd}\left(\mathrm{NO}_{3}\right)_{2}$ (Fluka, Cat. No. 76070) to prepare the monometallic catalysts. The concentration of the solutions was adjusted in order to obtain metal loading of 4 and $0.4 \mathrm{wt} \%$ of $\mathrm{Ni}$ and $\mathrm{Pd}$, respectively. The impregnated solids were dried during $24 \mathrm{~h}$ at $373 \mathrm{~K}$ and then they were calcined in an air flow at $823 \mathrm{~K}$ during $3 \mathrm{~h}$. Prior to reaction, the catalysts were reduced in hydrogen flow $\left(105 \mathrm{~mL} \mathrm{~min}^{-1}\right)$ during $1 \mathrm{~h}$ at $673 \mathrm{~K}$ for $\mathrm{Ni} / \mathrm{Al}_{2} \mathrm{O}_{3}$ and at $573 \mathrm{~K}$ for $\mathrm{Pd} / \mathrm{Al}_{2} \mathrm{O}_{3}$.

\subsection{Characterization}

\subsubsection{Chemical analysis}

The metal loadings of the catalysts were determined by digesting the samples and then analyzing the liquors by inductively coupled plasma analysis (ICP) in an OPTIMA 2100 DV Perkin Elmer equipment.

\subsubsection{X-Ray Photoelectron Spectroscopy (XPS)}

XPS determinations were made in Multitech UniSpecs XR-50 equipment with a dual Mg/Al X-ray source. A SPECS PHOIBOS 150 hemisphere analyzer was used in the Fixed Analyzer Transmission mode (FAT). The samples were treated $e x$ situ with a hydrogen flow during 1 $\mathrm{h}$ at the corresponding reduction temperature and in situ in the load camera of the 
instrument with a $\mathrm{H}_{2} / \mathrm{Ar}(5 \% \mathrm{v} / \mathrm{v})$ flow during $10 \mathrm{~min}$. The spectra were obtained using pass energy of $30 \mathrm{eV}$ and a $\mathrm{Mg}$ anode operated at $200 \mathrm{~W}$. During the tests the pressure was less than $210^{-12} \mathrm{MPa}$.

\subsubsection{X-Ray Diffraction (XRD)}

X-Ray Diffraction (XRD) measurements of the samples were obtained using a Shimadzu XDD1 instrument with $\mathrm{CuK} \alpha$ radiation $\left(\lambda=1.5405 \mathrm{~A}^{\circ}\right)$ in the $15<2 \theta<85^{\circ}$ at a scan speed of $1^{\circ}$ $\mathrm{min}^{-1}$. Samples were powdered and reduced under a hydrogen flow, then they were immediately put into the chamber of the equipment and the data acquisition was started.

\subsubsection{Temperature Programmed Reduction (TPR)}

The tests were performed in an Ohkura 2002 S apparatus equipped with a thermal conductivity detector. A cold water trap was placed before the thermal detector to condense water. Before the TPR tests the samples were dried in situ at $673 \mathrm{~K}$ for $30 \mathrm{~min}$ in an oxygen flow (AGA purity $99.99 \%$ ). After that the samples were cooled down up to $298 \mathrm{~K}$ in an argon flow. Then the temperature was increased up to $1223 \mathrm{~K}_{\text {at }} 10 \mathrm{~K} \mathrm{~min}^{-1}$ in a $\mathrm{H}_{2} / \mathrm{Ar}(5 \% \mathrm{v} / \mathrm{v})$ gas flow.

\subsubsection{Hydrogen chemisorption}

Hydrogen chemisorption was performed by means of the dynamic pulse method using a Micromeritics Auto Chem II apparatus equipped with a thermal conductivity detector. $0.2 \mathrm{~g}$ of the samples were reduced $1 \mathrm{~h}$ in situ at the above mentioned temperatures using a $\mathrm{H}_{2} / \mathrm{Ar}$ $(5 \% \mathrm{v} / \mathrm{v})$ flow. The samples were degassed in situ for $2 \mathrm{~h}$ under an argon flow (AGA, 99.99\%) at a temperature equal to that of the corresponding reduction step and then cooled down to room temperature. In the case of the palladium catalysts they were cooled down to $373 \mathrm{~K}$ to make the formation of palladium hydride negligible [16]. After that the chemisorption of hydrogen was performed until total saturation of the samples.

\subsection{Catalytic tests}

The partial hydrogenation of 1-heptyne was carried out in a stainless steel stirred batch reactor equipped with a magnetically coupled stirrer with two blades in counter-rotation that was operated at $800 \mathrm{rpm}$. The inner wall of the reactor was completely coated with PTFE lining in order to prevent the catalytic action of steel reported by other authors [17]. The tests were performed using the following conditions: partial pressure of $\mathrm{H}_{2}$ equal to 1.4, 1.9, 2.4 bar; reaction temperature: 293, 303, $323 \mathrm{~K}$; initial 1-heptyne concentration of 0.1019 , $0.1528,0.2038 \mathrm{~mol} \mathrm{~L}^{-1}$; particle size: fractions of 60 or 120 mesh and $1500 \mu \mathrm{m}$. 1-heptyne (Fluka, Cat. No. 51950, >98\%), the reactant, was dissolved in toluene (Merck, Cat. No. TX0735-44, $>99 \%$ ). $75 \mathrm{~mL}$ of the stock solution and catalyst samples of $0.3 \mathrm{~g}$ of $\mathrm{Ni} / \mathrm{Al}_{2} \mathrm{O}_{3}$ and $0.03 \mathrm{~g}$ of $\mathrm{Pd} / \mathrm{Al}_{2} \mathrm{O}_{3}$ previously reduced in hydrogen for $1 \mathrm{~h}$ at 673 and $573 \mathrm{~K}$, respectively, were used in the different catalytic tests. 
The evolutions of reactant and products concentrations with reaction time were followed by Gas Chromatography using a flame ionization detector (FID) and a capillary column $30 \mathrm{~m}$ J\&W INNOWax 19091N-213.

\section{Results and discussion}

\subsection{Catalysts characterization}

The metal loadings of the catalysts determined by ICP were 3.5 and $0.35 \mathrm{wt} \%$ of $\mathrm{Ni}$ and Pd, respectively.

For the monometallic $\mathrm{Ni} / \mathrm{Al}_{2} \mathrm{O}_{3}$ catalyst no hydrogen consumption was detected during the chemisorption analysis, in total accordance with previously reported results [18]. For the $\mathrm{Pd} / \mathrm{Al}_{2} \mathrm{O}_{3}$ catalyst a chemisorption value of $18 \mu \mathrm{mol} \mathrm{H} \mathrm{g}_{\mathrm{cat}^{-1}}$ was measured.

Figures 1 and 2 show the XPS spectra of $\mathrm{Ni} 2 \mathrm{p}_{3} / 2$ and $\mathrm{Pd} 3 \mathrm{~d}$ for $\mathrm{Ni} / \mathrm{Al}_{2} \mathrm{O}_{3}$ and $\mathrm{Pd} / \mathrm{Al}_{2} \mathrm{O}_{3}$ catalysts, respectively. It can be seen that the monometallic nickel catalyst presents two

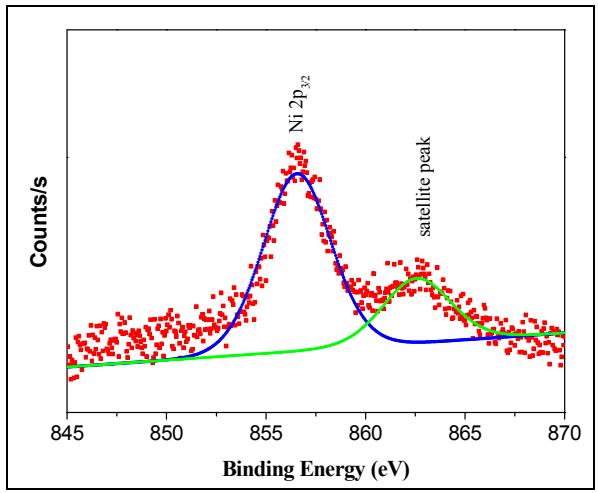

Figure 1. XPS Ni 2 $\mathrm{p}_{3 / 2}$ spectra of $\mathrm{Ni} / \mathrm{Al}_{2} \mathrm{O}_{3}$.

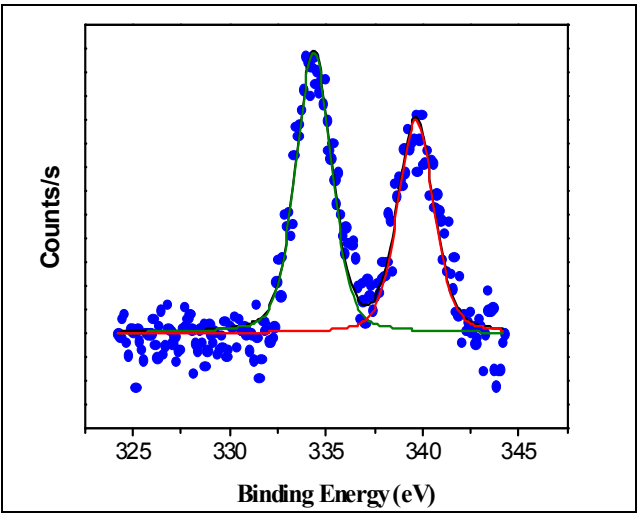

Figure 2. XPS Pd 3d spectra of $\mathrm{Pd} / \mathrm{Al}_{2} \mathrm{O}_{3}$ 
peaks, with maximums at $855.4 \mathrm{eV}$ and $862.6 \mathrm{eV}$. The former can be associated to $\mathrm{Ni}^{2+}$ species [19-22]; the other peak corresponds to the shake up of $\mathrm{Ni}(\mathrm{II})[25,28,29]$. According to the literature, the maximum BE of the $\mathrm{Pd} 3 \mathrm{~d}_{5} / 2$ peak of the monometallic palladium catalyst at $334.9 \mathrm{eV}$, with its $3 \mathrm{~d}_{3 / 2}$ doublet peak at $340.1 \mathrm{eV}$, corresponds to $\mathrm{Pd}^{0}$ [18-19,22-23].

The XRD difractograms of the catalysts only present the $\gamma$-alumina peaks at $2 \theta=37.7,46.0$ and 67.0 $0^{\circ}$ [24-26]. For this reason the difractograms are not shown. Because of the low amount of $\mathrm{Pd}$ or $\mathrm{Ni}$ on the $\mathrm{Pd} / \mathrm{Al}_{2} \mathrm{O}_{3}$ or $\mathrm{Ni} / \mathrm{Al}_{2} \mathrm{O}_{3}$ catalysts, the crystalline phases of palladium or nickel were undetectable. Several authors stated that high charges of nickel $\left(\gg 15\right.$ wt \%) are necessary to observe the peaks at $2 \theta=43.3^{\circ} ; 63.0^{\circ} ; 75.5^{\circ}$ and $79.5^{\circ}$ of $\mathrm{NiO}$ $[27,28]$.

Figure 3 shows the TPR traces of the studied catalysts. The TPR trace of the Pd monometallic catalyst had a main hydrogen consumption peak at $287 \mathrm{~K}$, which can be attributed to the reduction of $\mathrm{PdO}$ species and to the formation of palladium hydrides [29]. This catalyst also has an inverted reduction peak at $339 \mathrm{~K}$ that could be related to the decomposition of the $\beta$ $\mathrm{PdH}$ phase $[20,21,24]$. As these species interact weakly with the support the palladium hydrides are completely eliminated during reduction. Figure 3 also shows the profile of reduction of $\mathrm{Ni} / \mathrm{Al}_{2} \mathrm{O}_{3}$ catalyst, the principal reduction peak begins at $700 \mathrm{~K}$, finishes over $900 \mathrm{~K}$ and presents a maximum at $802 \mathrm{~K}$ which corresponds to the reduction of $\mathrm{NiO}\left(\mathrm{Ni}^{2+}\right.$ species) interacting with the alumina [30]. The second peak of minor intensity is observed at higher temperatures $(>1000 \mathrm{~K})$, and corresponds to the reduction of nickel aluminates [3132]. At the reduction temperature used during the preparation of the catalysts, the obtained TPR spectra suggest the presence of species $\mathrm{Ni}^{2+}$ and $\mathrm{Pd}^{0}$ on $\mathrm{Ni} / \mathrm{Al}_{2} \mathrm{O}_{3}$ and $\mathrm{Pd} / \mathrm{Al}_{2} \mathrm{O}_{3}$ catalysts, respectively. These results are in total agreement with the XPS results.

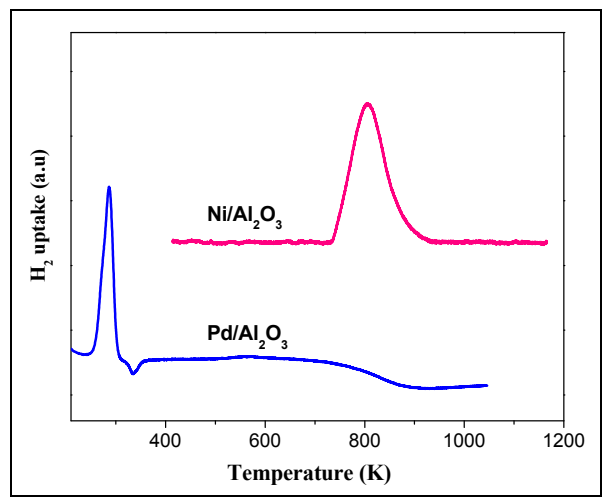

Figure 3. TPR traces of the $\mathrm{Ni} / \mathrm{Al}_{2} \mathrm{O}_{3}$ and $\mathrm{Pd} / \mathrm{Al}_{2} \mathrm{O}_{3}$ catalysts.

It must be noted that the characterization techniques suggest that, after the pretreatment conditions employed during the preparation of the catalysts, only one type of active site is present on each catalytic system. 


\subsection{Catalytic results}

\subsubsection{Partial hydrogenation of 1-heptyne}

Before considering kinetic expressions or comparing catalyst performances it is necessary to check whether the selected reaction system proceeds in kinetic regime. The possibility of external and internal diffusional limitations during the catalytic tests was thus experimentally assessed.

\subsubsection{Experimental verification of the absence of external and internal mass transfer limitations}

In order to eliminate external diffusional limitations, experiences were carried out using different stirring speeds in the range of 180-1400 rpm. It was found that at stirring rates higher than $500 \mathrm{rpm}$, 1-heptyne conversion values remained constant, indicating that external gasliquid limitations were absent. A stirring rate of $800 \mathrm{rpm}$ was therefore chosen for all the kinetic tests. On the other hand and in order to ensure that the catalytic results were not influenced by external and intraparticle mass transfer limitations, the catalyst pellets were milled to samples of different particle size: a fraction bigger than 100 mesh $(<150 \mu \mathrm{m})$, a fraction of $60-100$ mesh (250-150 $\mu \mathrm{m}$ ) and pellets of $1500 \mu \mathrm{m}$ (not milled). The obtained values of 1-heptyne conversion were the same for the two milled fractions indicating the absence of internal diffusional limitations. Then particles with sizes smaller than $250 \mu \mathrm{m}$ were used in all tests.

\subsubsection{Catalytic activity results}

The catalytic activity results for the partial hydrogenation of 1-heptyne are shown in Figures 4 and 5 , where it is represented the variation of 1-heptyne $\left(C_{A}\right)$ and 1-heptene $\left(C_{B}\right)$ concentration as a function of the reaction time for the $\mathrm{Ni} / \mathrm{Al}_{2} \mathrm{O}_{3}$ and $\mathrm{Pd} / \mathrm{Al}_{2} \mathrm{O}_{3}$ catalysts.

It can be clearly seen that $\mathrm{Pd}$ is more active than $\mathrm{Ni}$, even when using one tenth of the catalyst mass of the Ni catalyst. Reasons for the differences in reactivity can be found in the literature. Most authors report that when the metal is more electron deficient it becomes less active because alkynes are more weakly adsorbed [5,33]. Nothing however is commented about the role of hydrogen. The published reports do not give a clear explanation of the effect of each metal and for this reason kinetic modelling was used in this work to shed light on these issues.

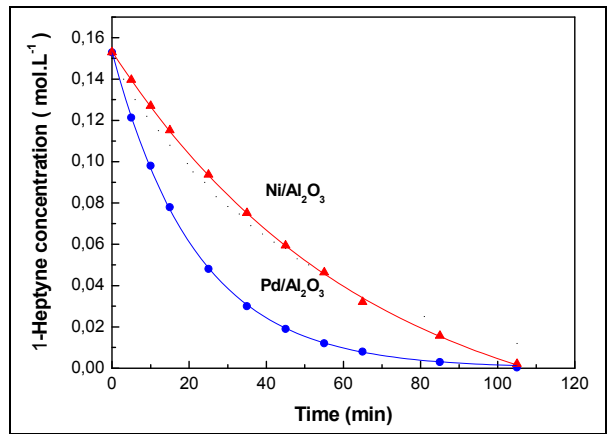

Figure 4. $\mathrm{C}_{\mathrm{A}}$ vs. reaction time. $\mathrm{P}_{\mathrm{H} 2}=1.4 \mathrm{bar}, \mathrm{C}_{\mathrm{A}}{ }_{\mathrm{A}}=0.1528 \mathrm{~mol} \mathrm{~L}^{-1}, \mathrm{~T}=323 \mathrm{~K}, 800 \mathrm{rpm}, \mathrm{W}_{\text {cat }}=0.3 \mathrm{~g}_{\mathrm{Ni} / \mathrm{Al} 2 \mathrm{O} 3}$ or $0.03 \mathrm{~g} \mathrm{Pd} / \mathrm{Al} 2 \mathrm{O} 3, \mathrm{~S} / \mathrm{Ni}=64$ and $\mathrm{S} / \mathrm{Pd}=29385$. 


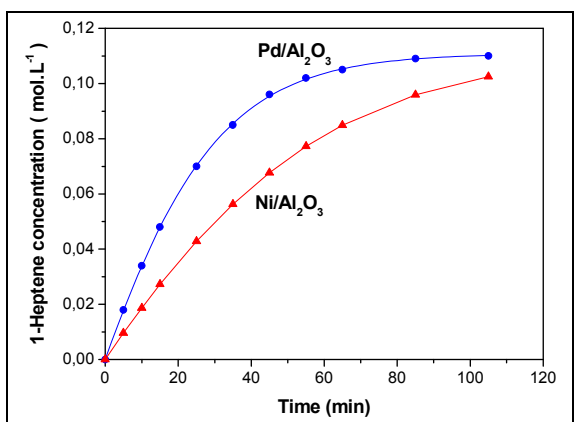

Figure 5. Св vs. reaction time. $\mathrm{P}_{\mathrm{H} 2}=1.4 \mathrm{bar}, \mathrm{C}_{0 \mathrm{~A}}=0.1528 \mathrm{~mol} \mathrm{~L}-1, \mathrm{~T}=323 \mathrm{~K}, 800 \mathrm{rpm}, \mathrm{W}_{\text {cat }}=0.3$ gNi/Al2O3 or $0.03 \mathrm{~g} \mathrm{Pd} / \mathrm{Al} 2 \mathrm{O} 3, \mathrm{~S} / \mathrm{Ni}=64$ and $\mathrm{S} / \mathrm{Pd}=29385$.

\section{Kinetic modeling}

\subsection{Reaction network}

A series-parallel reaction network was proposed for partial hydrogenation of 1-heptyne [14], as indicated in Figure 6.a. This is composed of three hydrogenation reactions that can be a priori considered reversible. The equilibrium constant for each of the previous reactions were calculated using Joback's group contribution method [34]. The values at $323 \mathrm{~K}$ were calculated as $\mathrm{K}_{1}=3.3510^{21}, \mathrm{~K}_{2}=1.8710^{35}$ and $\mathrm{K}_{3}=5.5810^{13}$. These values indicate that the individual reactions in Figure 6.a can be considered as irreversible. The experimentally obtained values of total conversion of 1-heptyne confirmed this prediction.

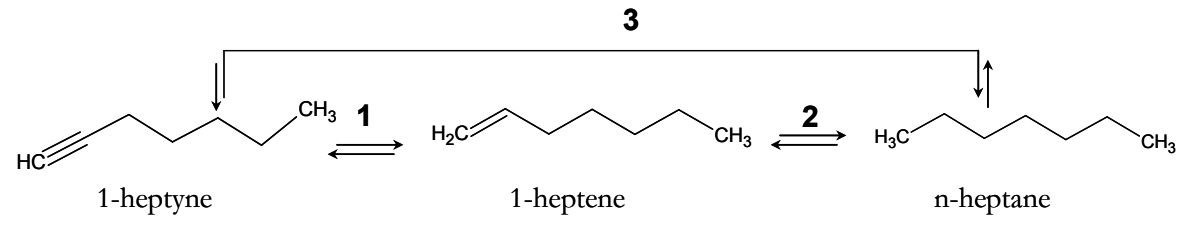

(a)<smiles>C#CCCCCC</smiles>

1-heptyne<smiles>C=CCCCCC</smiles>

1-heptene<smiles>C1CCCCC1</smiles>

(b)<smiles>CCCCCCCCCCCCCCCCC</smiles>

n-heptane

Figure 6. Reaction scheme for 1-heptyne (a) reversible hydrogenation and (b) irreversible hydrogenation.

Experimentally, it is observed that while 1-heptyne is present in the reaction medium, 1heptene concentration always increases, showing higher concentration than n-heptane. 
After all 1-heptyne was consumed, 1-heptene concentration begins to decrease very slowly and n-heptane concentration equally increases. These profiles are consistent with two reaction schemes: i) two parallel irreversible reactions (steps 1 and 3), and ii) series-parallel irreversible reactions, with a $\mathrm{k}_{1} / \mathrm{k}_{2}$ value higher than 100 . The latter considerations, allows us to disregard step 2. Therefore a simplified network of parallel reactions for 1-heptyne hydrogenation can be assumed in Figure 6.b.

\subsection{Langmuir-Hinshelwood-Hougen-Watson (LHHW) models}

Models of heterogeneous reactions were outlined using the Langmuir-HinshelwoodHougen-Watson formalism (LHHW models). Taking into account the previously presented characterization results of $\mathrm{Ni} / \mathrm{Al}_{2} \mathrm{O}_{3}$ and $\mathrm{Pd} / \mathrm{Al}_{2} \mathrm{O}_{3}$, in all the models only one type of active sites was considered to be present. Six different models with their respective basic hypotheses are presented in Table 1 . The elementary steps with $\mathrm{H}_{2}$ dissociative or nondissociative adsorption reaction mechanism are presented in Table 2.

\begin{tabular}{|c|c|c|c|}
\hline Mo- & Hypothesis of the model & Simplified Rate & Parameters \\
\hline I & $\begin{array}{l}\text { Controlling step: adsorption of } \\
\mathrm{H}_{2} \text {. Dissociative adsorption of } \\
\mathrm{H}_{2} \text { [42]. Competitive adsorption } \\
\text { of 1-heptyne and } \mathrm{H}_{2} \text {. Total } \\
\text { coverage of active sites. }\end{array}$ & $r=\frac{P_{3}}{\left[C_{A}+P_{1} \cdot C_{B}+P_{2} \cdot C_{C}\right]^{2}}$ & $\begin{array}{l}P_{1}=\frac{K_{B}}{K_{A}} \quad P_{2}=\frac{K_{C}}{K_{A}} \\
P_{3}=\frac{k_{H_{2}} \cdot C_{H_{2}} \cdot C_{S}^{2}}{K_{A}^{2}}\end{array}$ \\
\hline II & $\begin{array}{l}\text { Controlling step: adsorption } \\
\text { of 1-Heptyne. Dissociative } \\
\text { adsorption of } \mathrm{H}_{2} \text { [42]. } \\
\text { Competitive adsorption of 1- } \\
\text { heptyne and } \mathrm{H}_{2} \text {. Total } \\
\text { coverage of active sites. }\end{array}$ & $r=\frac{P_{6} \cdot C_{A}}{\left[1+P_{4} \cdot C_{B}+P_{5} \cdot C_{C}\right]}$ & $\begin{array}{l}P_{4}=\frac{K_{B}}{\sqrt{K_{H_{2}} \cdot C_{H_{2}}}} \\
P_{5}=\frac{K_{C}}{\sqrt{K_{H_{2}} \cdot C_{H_{2}}}}\end{array}$ \\
\hline III & $\begin{array}{l}\text { Controlling step: surface } \\
\text { chemical reaction. } \\
\text { Dissociative adsorption of } \mathrm{H}_{2} \\
\text { [42]. Competitive adsorption } \\
\text { of 1-heptyne and } \mathrm{H}_{2} \text {. Total } \\
\text { coverage of active sites. }\end{array}$ & $\begin{array}{l}r_{1}=\frac{P_{10} \cdot C_{A}}{\left[1+P_{7} \cdot C_{A}+P_{4} \cdot C_{B}+P_{5} \cdot C_{C}\right]^{3}} \\
r_{3}=\frac{P_{11} \cdot C_{A}}{\left[1+P_{7} \cdot C_{A}+P_{4} \cdot C_{B}+P_{5} \cdot C_{C}\right]^{3}}\end{array}$ & $\begin{array}{l}P_{6}=\frac{k_{A} \cdot C_{S}}{\sqrt{K_{H_{2}} \cdot C_{H_{2}}}} \\
P_{7}=\frac{\left(1+K \cdot K_{H_{2}} \cdot C_{H_{2}}\right) \cdot K_{A}}{\sqrt{K_{H_{2}} \cdot C_{H_{2}}}} \\
P_{10}=\frac{k_{1} \cdot K_{A} \cdot C_{S}^{3}}{\sqrt{K_{H_{2}} \cdot C_{H_{2}}}} \\
P_{11}=\frac{k_{3} \cdot K_{A} \cdot K \cdot C_{S}^{3}}{\sqrt{K_{H_{2}} \cdot C_{H_{2}}}}\end{array}$ \\
\hline IV & $\begin{array}{l}\text { Controlling step: adsorption } \\
\text { of } \mathrm{H}_{2} \text {. Non dissociative } \\
\text { adsorption of } \mathrm{H}_{2} \text { [43]. } \\
\text { Competitive adsorption of } 1- \\
\text { heptyne and } \mathrm{H}_{2} \text {. The active } \\
\text { sites are not completely } \\
\text { covered. }\end{array}$ & $r=\frac{P_{12}}{\left[1+K_{A} \cdot C_{A}+K_{B} \cdot C_{B}+K_{C} \cdot C_{C}\right]}$ & $P_{12}=k_{H_{2}}^{\prime} \cdot C_{H_{2}} \cdot C_{S}$ \\
\hline
\end{tabular}




\begin{tabular}{|l|l|l|l|}
\hline $\begin{array}{r}\text { Mo- } \\
\text { del }\end{array}$ & \multicolumn{1}{|c|}{ Hypothesis of the model } & \multicolumn{1}{c|}{ Simplified Rate } & \multicolumn{1}{c|}{ Parameters } \\
\hline $\mathrm{V}$ & $\begin{array}{l}\text { Controlling step: adsorption } \\
\text { of 1-Heptyne. Non } \\
\text { dissociative adsorption of } \mathrm{H}_{2} \\
\text { [43]. Competitive adsorption } \\
\text { of 1-heptyne and } \mathrm{H}_{2} \text {. The } \\
\text { active sites are not completely } \\
\text { covered. }\end{array}$ & $r=\frac{P_{14} \cdot C_{A}}{\left[1+P_{13}+K_{B} \cdot C_{B}+K_{C} \cdot C_{C}\right]}$ & $\begin{array}{l}P_{13}=K_{H_{2}}^{*} \cdot C_{H_{2}} \\
P_{14}=k_{A} \cdot C_{S}\end{array}$ \\
\hline VI & $\begin{array}{l}\text { lontrolling step: surface } \\
\text { chemical reaction. Non } \\
\text { dissociative adsorption of } \mathrm{H}_{2} \\
\text { [43]. Competitive adsorption } \\
\text { of 1-heptyne and } \mathrm{H}_{2} \text {. The } \\
\text { active sites are not completely } \\
\text { covered. }\end{array}$ & $r_{1}=\frac{P_{16} \cdot C_{A}}{\left[1+P_{13}+P_{15} \cdot C_{A}+K_{B} \cdot C_{B}+K_{C} \cdot C_{C}\right]^{2}}$ & $\begin{array}{l}r_{15}=\left(1+K^{*} \cdot K_{H_{2}}^{*} \cdot C_{H_{2}}\right) \cdot K_{A} \\
P_{16}=k_{1} \cdot K_{A} \cdot K_{H_{2}}^{*} \cdot C_{H_{2}} \cdot C_{S}^{2}\end{array}$ \\
$P_{17}=C_{A}+K_{B} \cdot C_{B}+K_{C} \cdot C_{C} \cdot K^{*} \cdot K_{H_{2}}^{*} \cdot C_{H_{2}}^{2} \cdot C_{S}^{2}$ \\
\hline
\end{tabular}

Table 1. LHHW kinetic models.

\begin{tabular}{|c|c|c|c|}
\hline \multicolumn{2}{|l|}{$\mathrm{H}_{2}$ dissociative adsorption. } & \multicolumn{2}{|l|}{$\mathrm{H}_{2}$ non dissociative adsorption. } \\
\hline $\mathrm{H}_{2}+2 \mathrm{~S} \Leftrightarrow 2 \mathrm{HS} \quad \mathrm{K}_{\mathrm{H}_{2}}=\frac{\mathrm{C}_{\mathrm{HS}}^{2}}{\mathrm{C}_{\mathrm{H}_{2}} \cdot \mathrm{C}_{\mathrm{S}}^{2}}$ & $(1)$ & $\mathrm{H}_{2}+\mathrm{S} \Leftrightarrow \mathrm{H}_{2} \mathrm{~S} \quad \mathrm{~K}_{\mathrm{H}_{2}}^{*}=\frac{\mathrm{C}_{\mathrm{H}_{\mathrm{S}} \mathrm{S}}}{\mathrm{C}_{\mathrm{H}_{2}} \cdot \mathrm{C}_{\mathrm{S}}}$ & (8) \\
\hline $\mathrm{A}+\mathrm{S} \Leftrightarrow \mathrm{AS} \quad \mathrm{K}_{\mathrm{A}}=\frac{\mathrm{C}_{\mathrm{AS}}}{\mathrm{C}_{\mathrm{A}} \cdot \mathrm{C}_{\mathrm{S}}}$ & $(2)$ & $\mathrm{K}_{\mathrm{A}}=\frac{\mathrm{C}_{\mathrm{AS}}}{\mathrm{C}_{\mathrm{A}} \cdot \mathrm{C}_{\mathrm{S}}}$ & (9) \\
\hline $\mathrm{AS}+2 \mathrm{HS} \rightarrow \mathrm{BS}+2 \mathrm{~S} \quad \mathrm{~K}_{1}=\infty$ & (3) & $\mathrm{AS}+\mathrm{H}_{2} \mathrm{~S} \rightarrow \mathrm{BS}+\mathrm{S} \quad \mathrm{K}_{1}=\infty$ & (10) \\
\hline $\mathrm{AS}+2 \mathrm{HS} \Leftrightarrow \mathrm{AH}_{2} \mathrm{~S}+2 \mathrm{~S} \quad \mathrm{~K}=\frac{\mathrm{C}_{\mathrm{AH}_{2} \mathrm{~S}} \cdot \mathrm{C}_{\mathrm{S}}^{2}}{\mathrm{C}_{\mathrm{AS}} \cdot \mathrm{C}_{\mathrm{HS}}^{2}}$ & $(4)$ & $\mathrm{AS}+\mathrm{H}_{2} \mathrm{~S} \Leftrightarrow \mathrm{AH}_{2} \mathrm{~S}+\mathrm{S} \quad \mathrm{K}^{*}=\frac{\mathrm{C}_{\mathrm{AH}_{2} \mathrm{~S}} \cdot \mathrm{C}_{\mathrm{S}}}{\mathrm{C}_{\mathrm{AS}} \cdot \mathrm{C}_{\mathrm{H}_{2} \mathrm{~S}}}$ & $(11)$ \\
\hline $\mathrm{AH}_{2} \mathrm{~S}+2 \mathrm{HS} \rightarrow \mathrm{CS}+2 \mathrm{~S} \quad \mathrm{~K}_{3}=\infty$ & $(5)$ & $\mathrm{AH}_{2} \mathrm{~S}+\mathrm{H}_{2} \mathrm{~S} \rightarrow \mathrm{CS}+\mathrm{S} \quad \mathrm{K}_{3}=\infty$ & (12) \\
\hline $\mathrm{BS} \Leftrightarrow \mathrm{B}+\mathrm{S} \quad \frac{1}{\mathrm{~K}_{\mathrm{B}}}=\frac{\mathrm{C}_{\mathrm{B}} \cdot \mathrm{C}_{\mathrm{S}}}{\mathrm{C}_{\mathrm{BS}}}$ & $(6)$ & $\frac{1}{K_{B}}=\frac{C_{B} \cdot C_{S}}{C_{B S}}$ & (13) \\
\hline $\mathrm{CS} \Leftrightarrow \mathrm{C}+\mathrm{S} \quad \frac{1}{\mathrm{~K}_{\mathrm{C}}}=\frac{\mathrm{C}_{\mathrm{C}} \cdot \mathrm{C}_{\mathrm{S}}}{\mathrm{C}_{\mathrm{CS}}}$ & $(7)$ & $\frac{1}{\mathrm{~K}_{\mathrm{C}}}=\frac{\mathrm{C}_{\mathrm{C}} \cdot \mathrm{C}_{\mathrm{S}}}{\mathrm{C}_{\mathrm{CS}}}$ & (14) \\
\hline
\end{tabular}

Table 2. Elementary steps with $\mathrm{H}_{2}$ dissociative or non-dissociative adsorption reaction mechanism.

\subsection{Mass balances}

The following mass balances for components in the liquid phase were considered for the reaction scheme of Figure 6.b, for 1-heptyne (A), 1-heptene (B) and n-heptane (C):

$$
\begin{gathered}
\mathrm{dC}_{\mathrm{A}} / \mathrm{dt}=-\mathrm{r}_{1}-\mathrm{r}_{3} \\
\mathrm{dC}_{\mathrm{B}} / \mathrm{dt}=\mathrm{r}_{1}
\end{gathered}
$$




$$
\mathrm{dC}_{\mathrm{C}} / \mathrm{dt}=\mathrm{r}_{3}
$$

initial conditions were: $\mathrm{t}=0 \mathrm{~min}, \mathrm{C}^{0} \mathrm{~A}=0.1528 \mathrm{~mol} \mathrm{~L}^{-1}, \mathrm{C}_{\mathrm{B}}{ }=\mathrm{C}^{0} \mathrm{C}=0 \mathrm{~mol} \mathrm{~L}-1$.

\subsection{Numerical resolution and statistics}

The system of differential equations (15)-(17) was solved numerically using the RungeKutta-Merson algorithm. The model parameter estimation was performed by a non-linear regression, using a Levenberg-Marquardt algorithm which minimized the objective function:

$$
S C D=\sum_{j}^{n}\left(C_{i, j}-C_{i, j}^{C A L C}\right)^{2}
$$

where $C_{i, j}$ and $C_{i, j}^{C A L C}$ are the experimental and the predicted concentration values, respectively, " $i$ " is the chemical compound and " $j$ " is the reaction time.

The model adequacy and the discrimination between models were determined using the model selection criterion (MSC), according to the following equation:

$$
M S C=\ln \left(\frac{\sum_{j}^{n}\left(C_{i, j}-\bar{C}_{i}\right)^{2}}{\sum_{j}^{n}\left(C_{i, j}-C_{i, j}^{C A L C}\right)^{2}}\right)-\left(\frac{2 p}{n}\right)
$$

where $\bar{C}_{i}$ is the average relative concentration; $\mathrm{p}$ is the amount of parameters fitted and $\mathrm{n}$ is the number of experimental data. In order to compare different models, the selected one is that leading to the highest MSC value.

The Standard Deviation (S) was calculated with the following equation:

$$
S=\sqrt{s^{2}}=\sqrt{\frac{\sum_{j}^{n}\left(C_{i, j}-C_{i, j}^{C A L C}\right)^{2}}{n-p}}
$$

\subsection{Model discrimination}

The first main requisite for appropriateness of a model should be that of physical significance. A priori this means that the model parameters adopt feasible real values. A second requisite is that of adequate statistical confidence, i.e. the parameters should lie in one as small as possible confidence interval.

The practical criteria for the selection of the kinetic models were:

1. The estimated values of the parameters must be positive and different from zero.

2. The upper and lower extremes of the confidence interval (95\%) must be positive. 
3. The amplitude of the confidence interval must be lower than the value of the estimated parameter.

The final model is selected from the set of models complying the above 1 to 3 conditions, as the model with the lowest SCD, the summation of squares of the deviations. Another condition is that the standard deviation is smaller than the value of the parameter. If differences are not big, then the model selection criterion (MSC) should be used. Appropriate models should have a MSC value greater than 4 .

\subsection{Kinetic models for the reaction}

Preliminary tests were performed in order to check the influence of the different variables on the reaction rate. These results will be used later in the model selection stage. The variables screened were the partial pressure of hydrogen, the initial concentration of 1heptyne and the reaction temperature. In order to analyze the influence of each variable a pseudo homogeneous reaction model was proposed in which the reaction rate was assumed to follow a potential law. The initial reaction rate should thus be written as:

$$
r_{A}^{0}=k \cdot\left(C_{A}^{0}\right)^{\alpha} \cdot\left(P_{H 2}\right)^{\beta}
$$

An Arrhenius dependent was supposed for the specific constant of reaction:

$$
k=A \cdot e^{\frac{-E_{A}}{R \cdot T}}
$$

\subsubsection{Influence of the partial pressure of hydrogen}

Several tests were performed at varying hydrogen partial pressures $(1.4,1.9$ and 2.4 bar) keeping all other variables constant $\left(\mathrm{C}^{0} \mathrm{~A}=0.1528 \mathrm{~mol} \mathrm{~L}^{-1}, \mathrm{~T}=303 \mathrm{~K}, 800 \mathrm{rpm}, \mathrm{W}_{\text {cat }}=0.3 \mathrm{~g}\right.$ $\mathrm{Ni} / \mathrm{Al}_{2} \mathrm{O}_{3}$ or $0.03 \mathrm{Pd} / \mathrm{Al}_{2} \mathrm{O}_{3}$ ). The partial pressure of hydrogen was calculated as the difference between the total pressure and the partial pressure of the solvent, since the partial pressures of 1-heptyne and the products was negligible. The pressure of the solvent at $303 \mathrm{~K}$ was determined using Antoine's equation (0.048 bar).

Experimental values of conversion of 1-heptyne as a function of time are plotted in Figures 7.a and 7.b. Both Figures show that as $\mathrm{P}_{\mathrm{H} 2}$ rises, 1-heptyne total conversion increases for $\mathrm{Ni} / \mathrm{Al}_{2} \mathrm{O}_{3}$ catalyst, but decrease for $\mathrm{Pd} / \mathrm{Al}_{2} \mathrm{O}_{3}$. The reaction order with respect to hydrogen $(\beta)$ was calculated from the linearized form of equation (21).

$$
\ln \left(r_{A}^{0}\right)=\ln \left[k \cdot\left(C_{A}^{0}\right)^{\alpha}\right]+\beta \cdot \ln \left(P_{H 2}\right)
$$

The initial reaction rates of 1-heptyne were calculated by polynomial differentiation of the traces of Figures 7.a and 7.b and extrapolation to zero reaction time. From the plot of $\ln \left(\mathrm{r}^{0} \mathrm{~A}\right)$ vs. $\ln \left(\mathrm{P}_{\mathrm{H} 2}\right)$, shown in Figures 8.a and 8.b, reaction order in hydrogen of 1.3 and -2.6 were calculated for $\mathrm{Ni} / \mathrm{Al}_{2} \mathrm{O}_{3}$ and for $\mathrm{Pd} / \mathrm{Al}_{2} \mathrm{O}_{3}$, respectively. The results indicate that: a) for 


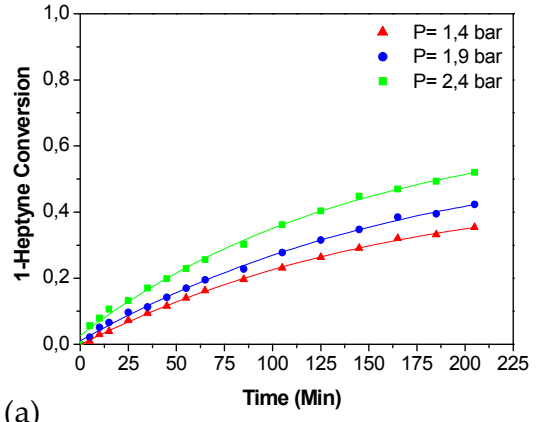

(a)

Figure 7. Effect of $\mathrm{P}_{\mathrm{H} 2}$ on the catalytic activity for (a) $\mathrm{Ni} / \mathrm{Al}_{2} \mathrm{O}_{3}$ and (b) $\mathrm{Pd} / \mathrm{Al}_{2} \mathrm{O}_{3} \cdot \mathrm{C}_{\mathrm{A}}=0.1528 \mathrm{~mol} \mathrm{~L}^{-1}$, $\mathrm{T}=303 \mathrm{~K}, 800 \mathrm{rpm}, \mathrm{W}_{\mathrm{cat}}=0.3 \mathrm{gNi} / \mathrm{Al} 2 \mathrm{O} 3$ or $0.03 \mathrm{~g} \mathrm{Pd} / \mathrm{Al} 2 \mathrm{O} 3, \mathrm{~S} / \mathrm{Ni}=64$ and $\mathrm{S} / \mathrm{Pd}=29385$.

$\mathrm{Ni} / \mathrm{Al}_{2} \mathrm{O}_{3}$ catalyst, high hydrogen partial pressures are beneficial for the reaction kinetics, probably both adsorption and surface reaction elementary steps could be enhanced; and b) an increase in the partial pressure of hydrogen negatively affects the reaction rate for $\mathrm{Pd} / \mathrm{Al}_{2} \mathrm{O}_{3}$.

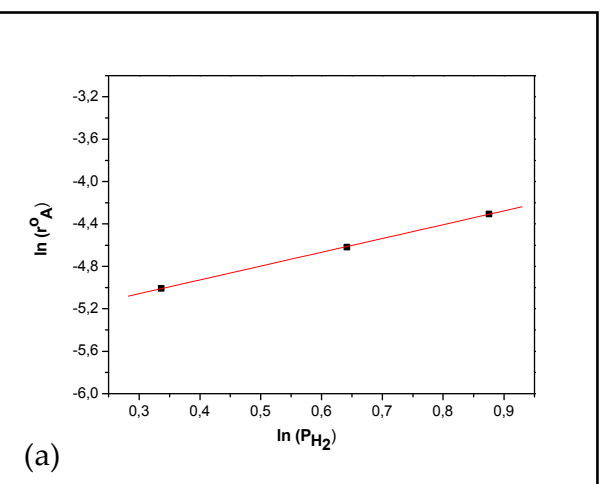

(a)

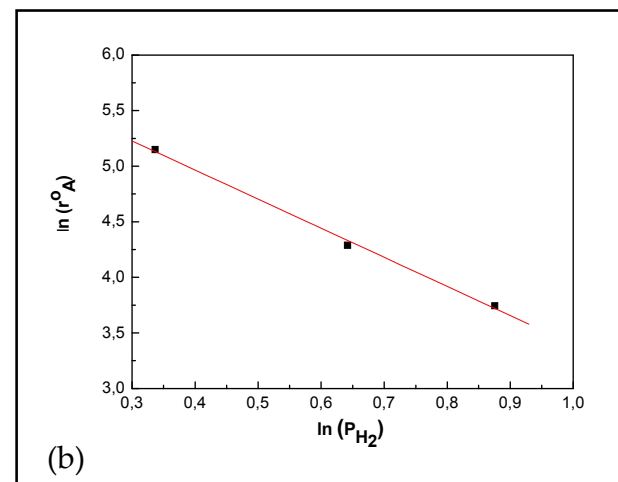

Figure 8. Initial reaction rate as a function of hydrogen pressure for (a) $\mathrm{Ni} / \mathrm{Al}_{2} \mathrm{O}_{3}$ and (b) $\mathrm{Pd} / \mathrm{Al}_{2} \mathrm{O}_{3}$. $\mathrm{C}^{0}{ }_{\mathrm{A}}=0.1528 \mathrm{~mol} \mathrm{~L}^{-1}, \mathrm{~T}=303 \mathrm{~K}, 800 \mathrm{rpm}, \mathrm{W}_{\mathrm{cat}}=0.3 \mathrm{gNi} / \mathrm{Al2O}$ or $0.03 \mathrm{~g} \mathrm{Pd} / \mathrm{Al} 2 \mathrm{O}, \mathrm{S} / \mathrm{Ni}=64$ and $\mathrm{S} / \mathrm{Pd}=29385$.

\subsubsection{Influence of the initial concentration of 1-heptyne}

Catalytic tests were performed varying the initial concentration of 1-heptyne: $0.1019,0.1528$ and $0.2038 \mathrm{~mol} \mathrm{~L}^{-1}$, keeping all the rest of the variables constant $\left(\mathrm{P}_{\mathrm{H} 2}=1.4 \mathrm{bar}, \mathrm{T}=303 \mathrm{~K}, 800\right.$ $\mathrm{rpm}, \mathrm{W}_{\text {cat }}=0.3 \mathrm{~g} \mathrm{Ni} / \mathrm{Al}_{2} \mathrm{O}_{3}$ or $\left.0.03 \mathrm{Pd} / \mathrm{Al}_{2} \mathrm{O}_{3}\right)$.

The obtained values of conversion of 1-heptyne as a function of time are plotted in Figures 9.a and 9.b. It can be seen that for both catalysts the catalytic activity is decreased when the initial concentration of 1-heptyne is increased. 

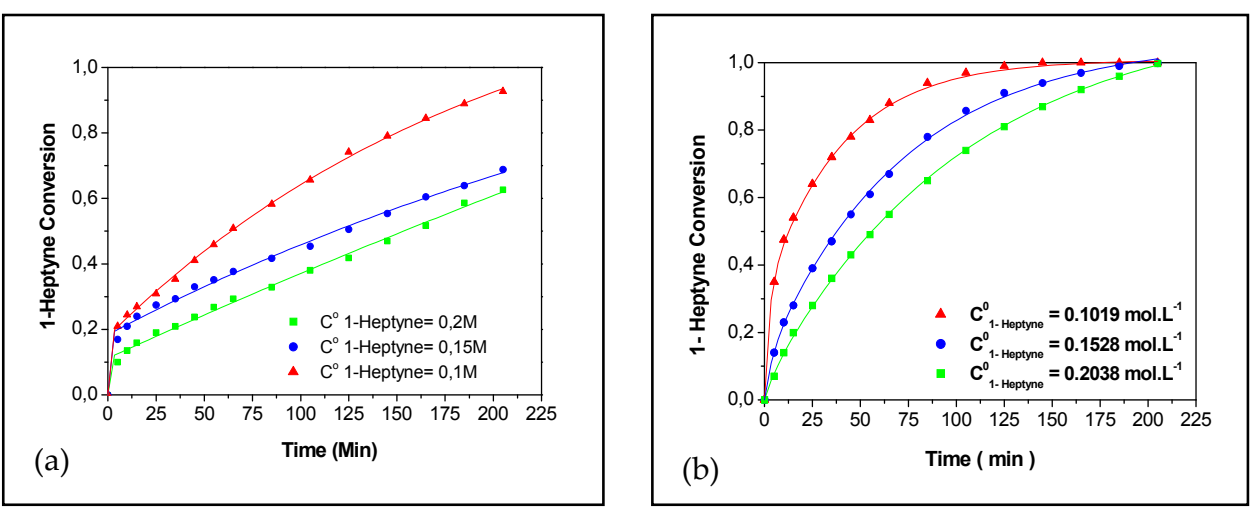

Figure 9. Effect of $\mathrm{C}^{0}$ on the catalytic activity for (a) $\mathrm{Ni} / \mathrm{Al}_{2} \mathrm{O}_{3}$ and (b) $\mathrm{Pd} / \mathrm{Al}_{2} \mathrm{O}_{3}$. $\mathrm{PH}_{2}=1.4$ bar, $\mathrm{T}=303 \mathrm{~K}$, $800 \mathrm{rpm}, \mathrm{W}_{\mathrm{cat}}=0.3 \mathrm{gNi} / \mathrm{Al2O}$ or $0.03 \mathrm{~g} \mathrm{Pd} / \mathrm{Al2O}, \mathrm{S} / \mathrm{Ni}=42,64$ and 85, S/Pd =19596, 29335 and 39192.
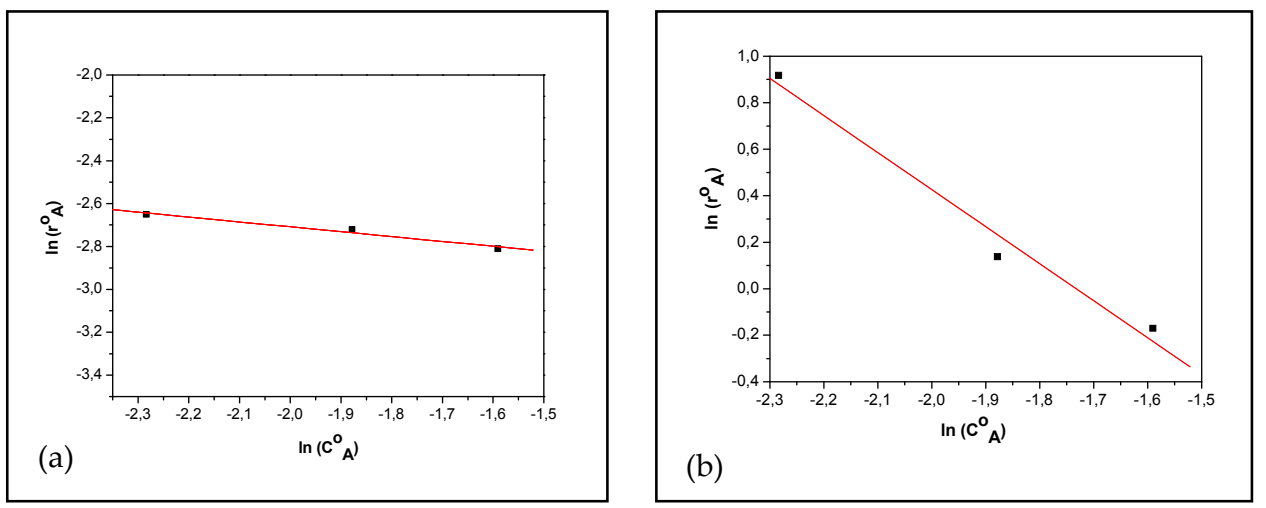

Figure 10. Initial reaction rate of 1-heptyne concentration for (a) $\mathrm{Ni} / \mathrm{Al}_{2} \mathrm{O}_{3}$ and (b) $\mathrm{Pd} / \mathrm{Al}_{2} \mathrm{O}_{3}$. $\mathrm{PH}_{2}=1.4$ bar, $\mathrm{T}=303 \mathrm{~K}, 800 \mathrm{rpm}, \mathrm{W}_{\mathrm{cat}}=0.3 \mathrm{gNi} / \mathrm{Al2O} 3$ or $0.03 \mathrm{~g} \mathrm{Pd} / \mathrm{Al2O}, \mathrm{S} / \mathrm{Ni}=42,64$ and 85, S/Pd =19596, 29335 and 39192.

The value of the reaction order in 1-heptyne $(\alpha)$ can be calculated along the lines described in the previous section:

$$
\ln \left(r_{A}^{0}\right)=\ln \left[k \cdot\left(P_{H 2}\right)^{\beta}\right]+\alpha \cdot \ln \left(C_{A}^{0}\right)
$$

The graph of $\ln \left(\mathrm{r}^{0} \mathrm{~A}\right)$ vs. $\ln \left(\mathrm{C}^{0} \mathrm{~A}\right)$, Figures 10.a and 10.b, yields value of order of reaction of 1heptyne equal to -0.22 and -1.5 for $\mathrm{Ni} / \mathrm{Al}_{2} \mathrm{O}_{3}$ and $\mathrm{Pd} / \mathrm{Al}_{2} \mathrm{O}_{3}$, respectively. The results indicate that an increase in the initial concentration of 1-heptyne is detrimental to the reaction rates.

\subsubsection{Influence of the reaction temperature}

Catalytic tests were performed varying the reaction temperature: 293, 303 and $323 \mathrm{~K}$, and keeping the rest of the variables constant $\left(\mathrm{P}_{\mathrm{H} 2}=1.4 \mathrm{bar}, \mathrm{C}_{\mathrm{A}}{ }=0.1528 \mathrm{~mol} \mathrm{~L}^{-1}, 800 \mathrm{rpm}, \mathrm{W}_{\text {cat }}=\right.$ $0.3 \mathrm{~g} \mathrm{Ni} / \mathrm{Al}_{2} \mathrm{O}_{3}$ or $\left.0.03 \mathrm{Pd} / \mathrm{Al}_{2} \mathrm{O}_{3}\right)$. 
The experimental values of conversion of 1-heptyne as a function of time at different temperature values are plotted in Figures 11.a and 11.b. As expected the activity of the catalyst is increased while the reaction temperature is raised up.
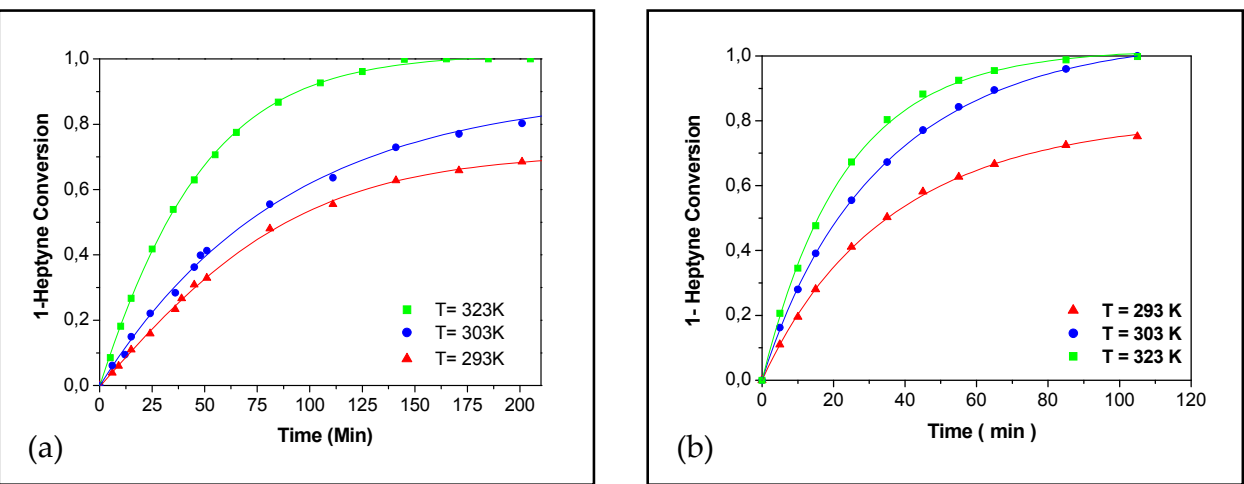

Figure 11. Effect of $\mathrm{T}$ on the catalytic activity for (a) $\mathrm{Ni} / \mathrm{Al}_{2} \mathrm{O}_{3}$ and (b) $\mathrm{Pd} / \mathrm{Al}_{2} \mathrm{O}_{3}$. $\mathrm{P}_{\mathrm{H}}=1.4 \mathrm{bar}, 800 \mathrm{rpm}$,

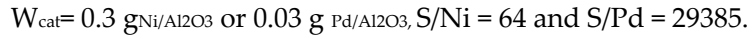

When equation (21) is linearized a value of "apparent" activation energy (EA) can be got, as indicated in Eq. (25):

$$
\ln \left(r_{A}^{0}\right)=\ln \left[A \cdot\left(P_{H 2}\right)^{\beta} \cdot\left(C_{A}^{0}\right)^{\alpha}\right]-\frac{E_{A}}{R \cdot T}
$$

The initial reaction rates of 1-heptyne were calculated as in the previous sections. The value of the apparent activation energy were obtained from the plots presented in Figure 12 of $\ln \left(\mathrm{r}^{0} \mathrm{~A}\right)$ as a function of $1 / \mathrm{T}$. The calculated values were 24 and $18 \mathrm{KJ} \mathrm{mol}^{-1}$ for $\mathrm{Ni} / \mathrm{Al}_{2} \mathrm{O}_{3}$ and $\mathrm{Pd} / \mathrm{Al}_{2} \mathrm{O}_{3}$, respectively. These values have not a real physical meaning and are only apparent.

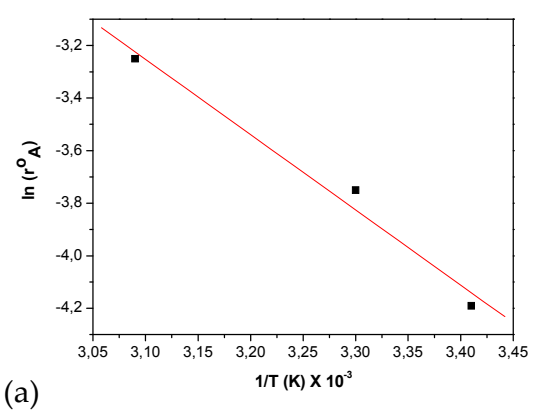

Figure 12. Temperature dependence of the reaction rate for (a) $\mathrm{Ni} / \mathrm{Al}_{2} \mathrm{O}_{3}$ and (b) $\mathrm{Pd} / \mathrm{Al}_{2} \mathrm{O}_{3}$. $\mathrm{PH}_{2}=1.4$ bar, $\mathrm{T}=303 \mathrm{~K}, 800 \mathrm{rpm}, \mathrm{W}_{\mathrm{cat}}=0.3 \mathrm{gNi}_{\mathrm{N} / \mathrm{Al} 2 \mathrm{O} 3}$ or $0.03 \mathrm{~g} \mathrm{Pd} / \mathrm{Al2O}, \mathrm{S} / \mathrm{Ni}=64$ and $\mathrm{S} / \mathrm{Pd}=29385$. 


\subsubsection{Model discrimination for $\mathrm{Ni} / \mathrm{Al}_{2} \mathrm{O}_{3}$ catalyst}

Models II, III, V and VI of Table 1 were discarded because they could not explain the negative and positive orders in 1-heptyne and hydrogen obtained experimentally. The parameters estimated for the models I and IV are indicated in Table 3. A statistical analysis was performed to discriminate between the different models, by means of the selection criteria described in Section 4.5. The results of this analysis are detailed in Table 3. It can be concluded that the best fit is achieved with model I- B. In this model the value of $\mathrm{P}_{2}$ is equal to zero, indicating that n-heptane is not adsorbed. The model IV-D also shows a good fit of the experimental data, but a pseudo homogeneous kinetic expression is obtained with different reaction orders than those previously calculated.

\begin{tabular}{|c|c|c|c|c|c|c|c|c|}
\hline $\begin{array}{l}\text { Mo- } \\
\text { del }\end{array}$ & $\begin{array}{l}\text { Op- } \\
\text { tion }\end{array}$ & Estimated parameter $\left.{ }^{*}\right)$ & SCD & MSC & $\begin{array}{l}\text { Para- } \\
\text { meter }\end{array}$ & $\begin{array}{l}\text { Para- } \\
\text { meter } \\
\text { sign }\end{array}$ & Discrimination & $\begin{array}{c}\text { Viabi- } \\
\text { lity }\end{array}$ \\
\hline \multirow[b]{2}{*}{ I } & A & $\begin{array}{c}\mathrm{P}_{1}=4.4823237 \pm 168.14985673 \\
\mathrm{P}_{2}=3.44577501 \pm 335.92334499 \\
\mathrm{P}_{3}= \\
0.0001211222587 \pm 0.00003376836\end{array}$ & $2.1 .10^{-3}$ & 3.7 & $\begin{array}{l}\mathrm{P}_{1} \\
\mathrm{P}_{2} \\
\mathrm{P}_{3}\end{array}$ & $\begin{array}{l}(+) \\
(+) \\
(+)\end{array}$ & $\begin{array}{l}\mathrm{IC}<0, \mathrm{CL}>\mathrm{VE} \\
\mathrm{IC}<0, \mathrm{CL}>\mathrm{VE} \\
\mathrm{IC}<0, \mathrm{CL}>\mathrm{VE}\end{array}$ & $\begin{array}{c}\text { Not } \\
\text { viable }\end{array}$ \\
\hline & B & $\begin{array}{c}\mathrm{P}_{2}=0 \\
\mathrm{P}_{1}=5.93108434 \pm 0.97784253 \\
\mathrm{P}_{3}= \\
0.000113720472 \pm 0.000026730661\end{array}$ & $2.10^{-3}$ & 4.5 & $\begin{array}{c}\mathrm{P}_{2}=0 \\
\mathrm{P}_{1} \\
\mathrm{P}_{3}\end{array}$ & $\begin{array}{l}(+) \\
(+)\end{array}$ & $\begin{array}{l}\mathrm{IC}>0, C L<\mathrm{VE} \\
\mathrm{IC}>0, \mathrm{CL}<\mathrm{VE}\end{array}$ & Viable \\
\hline \multirow{4}{*}{ IV } & A & $\begin{array}{c}\mathrm{K}_{\mathrm{A}}=8.34221367 \pm 355.9610964 \\
\mathrm{~K}_{B}=-1097.26187 \pm 7313.33134 \\
\mathrm{~K}_{C}=2384.39316 \pm 12837.26474 \\
P_{12}=0.00654481117 \pm 0.15591798\end{array}$ & $2.47 .10^{-4}$ & 5.17 & $\begin{array}{l}\mathrm{K}_{\mathrm{A}} \\
\mathrm{K}_{\mathrm{B}} \\
\mathrm{K}_{\mathrm{C}} \\
\mathrm{P}_{12}\end{array}$ & $\begin{array}{l}+(+) \\
(-) \\
(+) \\
(+)\end{array}$ & $\begin{array}{l}\mathrm{IC}<0, \mathrm{CL}>\mathrm{VE} \\
\mathrm{IC}<0, \mathrm{CL}>\mathrm{VE} \\
\mathrm{IC}<0, \mathrm{CL}>\mathrm{VE} \\
\mathrm{IC}<0, \mathrm{CL}>\mathrm{VE}\end{array}$ & $\begin{array}{c}\text { Not } \\
\text { viable }\end{array}$ \\
\hline & B & $\begin{array}{c}\mathrm{K}_{\mathrm{A}}=-6.36443252 \pm 3.54535551 \\
\mathrm{~K}_{\mathrm{B}}=0 \\
\mathrm{~K}_{\mathrm{C}}=-17.1237873 \pm 50.0933591 \\
\mathrm{P}_{12}=7.82119826 .10^{-5} \pm 1.570645 .10^{-3}\end{array}$ & $2.47 .10^{-4}$ & 5.23 & $\begin{array}{c}\mathrm{K}_{\mathrm{A}} \\
\mathrm{K}_{\mathrm{B}}=0 \\
\mathrm{~K}_{\mathrm{C}} \\
\mathrm{P}_{12}\end{array}$ & $\begin{array}{l}(-) \\
(-) \\
(+)\end{array}$ & $\begin{array}{l}\mathrm{IC}<0, \mathrm{CL}>\mathrm{VE} \\
\mathrm{IC}<0, \mathrm{CL}>\mathrm{VE} \\
\mathrm{IC}<0, \mathrm{CL}>\mathrm{VE}\end{array}$ & $\begin{array}{c}\text { Not } \\
\text { viable }\end{array}$ \\
\hline & C & $\begin{array}{c}\mathrm{K}_{\mathrm{A}}=-5.14858364 \pm 0.29479977 \\
\mathrm{~K}_{\mathrm{B}}=0 \\
\mathrm{~K}_{\mathrm{C}}=0 \\
\mathrm{P}_{12}=0.000613057924 \pm 3.87 .10^{-5}\end{array}$ & $2 \cdot 47.10^{-4} \mid$ & 5.21 & $\begin{array}{c}\mathrm{K}_{\mathrm{A}} \\
\mathrm{K}_{\mathrm{B}}=0 \\
\mathrm{~K}_{\mathrm{C}}=0 \\
\mathrm{P}_{12}\end{array}$ & $\begin{array}{l}(-) \\
(+)\end{array}$ & $\begin{array}{l}\mathrm{IC}<0, \mathrm{CL}>\mathrm{VE} \\
\mathrm{IC}<0, \mathrm{CL}>\mathrm{VE}\end{array}$ & $\begin{array}{c}\text { Not } \\
\text { viable }\end{array}$ \\
\hline & D & $\begin{array}{c}\mathrm{K}_{\mathrm{A}}=0 \\
\mathrm{~K}_{\mathrm{B}}=0 \\
\mathrm{~K}_{\mathrm{C}}=0 \\
\mathrm{P}_{12} \neq 0 \\
\text { A pseudohomogeneous model is } \\
\text { obtained. }\end{array}$ & & & $\begin{array}{l}\mathrm{K}_{\mathrm{A}}=0 \\
\mathrm{~K}_{\mathrm{B}}=0 \\
\mathrm{~K}_{\mathrm{C}}=0 \\
\mathrm{P}_{12} \neq 0\end{array}$ & & & Viable \\
\hline
\end{tabular}

Reaction conditions: $\mathrm{P}_{\mathrm{H} 2}=1.4$ bar, $\mathrm{T}=323 \mathrm{~K}, \mathrm{~W}_{\text {cat }}=0.3 \mathrm{~g}$, stirring rate $=800 \mathrm{rpm}, \mathrm{C}_{\mathrm{A}}^{0}=0.1528 \mathrm{~mol} . \mathrm{L}^{-1}, \mathrm{~S} / \mathrm{Ni}=64$. $\left({ }^{*}\right)$ 95\% confidence interval. IC: confidence interval; CL: confidence level; VE: estimated parameter value

Table 3. Estimated parameters and model discrimination for $\mathrm{Ni} / \mathrm{Al}_{2} \mathrm{O}_{3}$.

Figure 13 contains experimental values of the concentration of 1-heptyne, 1-heptene and nheptane along with theoretical values (solid line) estimated with model I-B, as a function of 
time. A good fit between the two sets of values can be seen. The same regression with model I-B was done with experimental data obtained at other reaction temperatures in the 293-323 $\mathrm{K}$ range. In all cases and as a consequence of the fit, parameters different from zero were obtained for a confidence interval of $95 \%$ and with values of the MSC parameter greater than 4.0. The thermodynamic consistency of the $\mathrm{P}_{1}$ and $\mathrm{P}_{3}$ parameters was graphically evaluated by plotting $\ln \mathrm{P}_{1}$ and $\ln \mathrm{P}_{3}$ as a function of $1 / \mathrm{T}$. In both cases a straight line was obtained (Figure 14) indicating that the constants have an Arrhenius dependence on temperature.

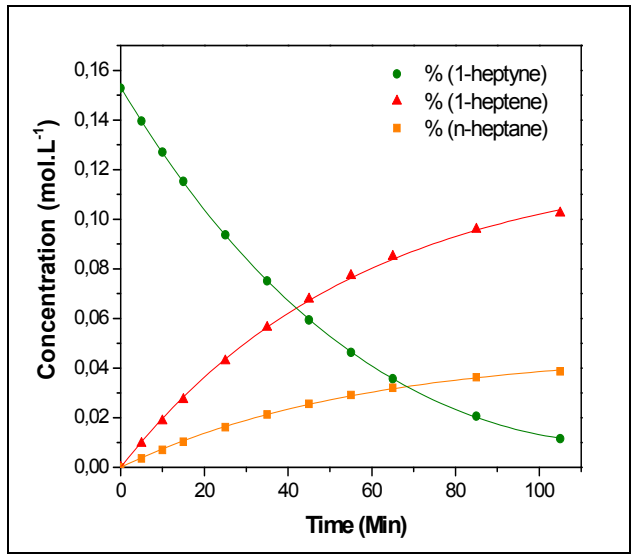

Figure 13. Fit of the experimental data of $\mathrm{C}_{i}$ as a function of time with model I-B for Ni/Al $\mathrm{Al}_{2} \mathrm{O}_{3}$ catalyst. $\mathrm{P}_{\mathrm{H} 2}=1.4$ bar, $\mathrm{C}_{\mathrm{A}}=0.1528 \mathrm{~mol} \mathrm{~L}^{-1}, 323 \mathrm{~K}, \mathrm{~W}_{\mathrm{cat}}=0.3 \mathrm{~g}, \mathrm{~S} / \mathrm{Ni}=64$.

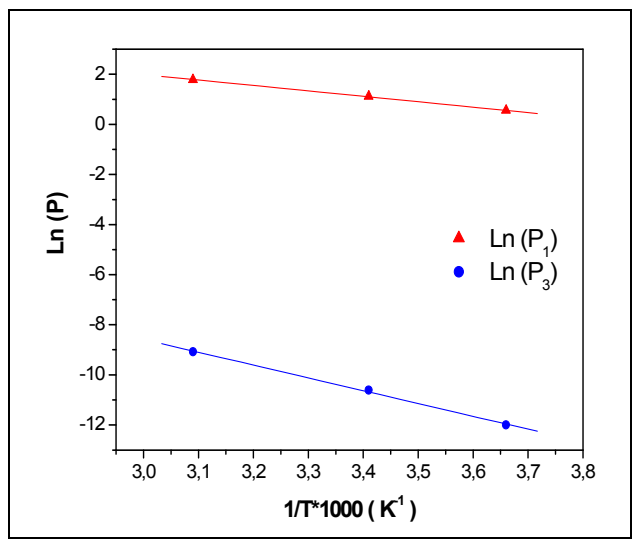

Figure 14. Temperature dependence of parameters $\mathrm{P}_{1}$ and $\mathrm{P}_{3}$ for $\mathrm{Ni} / \mathrm{Al}_{2} \mathrm{O}_{3}$ catalyst

The slopes of the straight lines correspond to the values of the enthalpies of adsorption of 1heptyne and 1-heptene and the value of the energy of activation for the dissociative adsorption of hydrogen on the active sites. Considering the definition of $\mathrm{P}_{1}$ and $\mathrm{P}_{3}$, the following equations can be obtained: 


$$
\begin{gathered}
P_{1}=\frac{K_{B}}{K_{A}}=\left(\frac{A_{B}}{A_{A}}\right) \cdot \operatorname{Exp}\left[\frac{\left|\Delta H_{B}\right|-\left|\Delta H_{A}\right|}{R \cdot T}\right] \\
P_{3}=\frac{C_{H 2} \cdot k_{H 2} \cdot C_{S}^{2}}{K_{A}^{2}}=\left(\frac{C_{H 2} \cdot A_{H 2} \cdot C_{S}^{2}}{A_{A}^{2}}\right) \cdot \operatorname{Exp}\left[\frac{-\left(E_{H 2}+2 \cdot\left|\Delta H_{A}\right|\right)}{R \cdot T}\right]
\end{gathered}
$$

In equations (26) and (27) the enthalpies of adsorption of 1-heptyne and 1-heptene were expressed in absolute values. The obtained values from the slopes of the lines in Figure 14 were:

$$
\begin{gathered}
\left|\Delta H_{B}\right|-\left|\Delta H_{A}\right|=-17.91 \mathrm{KJ} \mathrm{mol}^{-1} \\
E_{H 2}+2 \cdot\left|\Delta H_{A}\right|=58 \mathrm{KJ} \mathrm{mol}^{-1}
\end{gathered}
$$

Considering that $\left|\Delta H_{B}\right| \approx 0$, in accord with the experimental results, a value of the enthalpy of adsorption for 1-heptyne can be obtained from equation (28): $\Delta H_{A}=-17.91 \mathrm{KJ} \mathrm{mol}^{-1}$. Introducing this value in equation (29) a value of $\mathrm{EH}_{2}$ of $22.2 \mathrm{KJ} \mathrm{mol}^{-1} \mathrm{can}$ be estimated.

From the results it could be concluded that:

1. Model I-B that supposes dissociative adsorption of hydrogen as the rate-controlling step of reaction and a single type of active sites with total coverage, is the one that best fits experimental data with statistical and thermodynamic consistency.

2. The model does not allow to directly obtain the enthalpies of adsorption of 1-heptyne and 1-heptene and the activation energy for the adsorption of hydrogen.

3. From equation (28) it can be inferred that the enthalpy of adsorption of 1-heptyne is greater than that of 1-heptene, in agreement with the information available in the literature on the partial hydrogenation of alkynes [34].

4. This model also supposes that the alkane is not adsorbed. If we additionally suppose that the enthalpy of adsorption of 1-heptene is negligible, in accordance with experimental results, a value of the enthalpy of adsorption of 1-heptyne and activation energy for the $\mathrm{H}_{2}$ adsorption can be obtained from eqs. (28) and (29).

Then, it can be concluded that the dissociative adsorption of $\mathrm{H}_{2}$ is the rate limiting step for the $\mathrm{Ni} / \mathrm{Al}_{2} \mathrm{O}_{3}$ catalyst, and that the active sites are preferentially occupied by 1-heptyne.

\subsubsection{Model discrimination for the $\mathrm{Pd}_{/} \mathrm{Al}_{2} \mathrm{O}_{3}$ catalyst}

Models I, II, IV and V of Table 1 were discarded because they could not explain the negative orders in 1-heptyne and hydrogen obtained experimentally. The parameters estimated for the models III and VI are indicated in Table 4. A statistical analysis was performed to discriminate between the different models, by means of the selection criteria described in Section 4.5. The results of this analysis are detailed in Table 4; these results indicate that model III-C gives the best fit of the experimental data. In this model the value of the 
parameters $\mathrm{P}_{4}$ and $\mathrm{P}_{5}$ are equal to zero. Therefore the only species being adsorbed on the $\mathrm{Pd} / \mathrm{Al}_{2} \mathrm{O}_{3}$ catalyst are 1-heptyne and hydrogen.

\begin{tabular}{|c|c|c|c|c|c|c|c|c|}
\hline $\begin{array}{l}\text { Mo- } \\
\text { del }\end{array}$ & $\begin{array}{l}\text { Op- } \\
\text { tion }\end{array}$ & Estimated parameter $\left(^{*}\right)$ & SCD & MSC & $\begin{array}{l}\text { Para- } \\
\text { meter }\end{array}$ & $\begin{array}{l}\text { Para- } \\
\text { meter } \\
\text { sign }\end{array}$ & Discrimination & $\begin{array}{c}\text { Viabi- } \\
\text { lity }\end{array}$ \\
\hline \multirow{3}{*}{ III } & A & $\begin{aligned} P_{4} & =-53.0866055 \pm 3399.8626255 \\
P_{5} & =221.348971 \pm 7134.846189 \\
P_{7} & =28.7488806 \pm 370.8944874 \\
P_{10} & =4.68720094 \pm 147.04798306 \\
P_{11} & =1.92159358 \pm 60.33982722\end{aligned}$ & $2 \cdot 2 \cdot 10^{-4}$ & 5.206 & $\begin{array}{l}\mathrm{P}_{4} \\
\mathrm{P}_{5} \\
\mathrm{P}_{7} \\
\mathrm{P}_{10} \\
\mathrm{P}_{11}\end{array}$ & $\begin{array}{l}(-) \\
(+) \\
(+) \\
(+) \\
(+)\end{array}$ & $\begin{array}{l}\mathrm{IC}<0, \mathrm{CL}>\mathrm{VE} \\
\mathrm{IC}<0, \mathrm{CL}>\mathrm{VE} \\
\mathrm{IC}<0, \mathrm{CL}>\mathrm{VE} \\
\mathrm{IC}<0, \mathrm{CL}>\mathrm{VE} \\
\mathrm{IC}<0, \mathrm{CL}>\mathrm{VE}\end{array}$ & $\begin{array}{l}\text { Not } \\
\text { viable }\end{array}$ \\
\hline & B & $\begin{array}{c}P_{4}=0 \\
P_{5}=73.3086809 \pm 919.4831331 \\
P_{7}=23.0235065 \pm 284.1617705 \\
P_{10}=2.75603228 \pm 79.34470502 \\
P_{11}=1.12978185 \pm 32.52404635\end{array}$ & $2 \cdot 2 \cdot 10^{-4}$ & 5.266 & $\begin{array}{l}P_{5} \\
P_{7} \\
P_{10} \\
P_{11}\end{array}$ & $\begin{array}{l}(+) \\
(+) \\
(+) \\
(+)\end{array}$ & $\begin{array}{l}\mathrm{IC}<0, \mathrm{CL}>\mathrm{VE} \\
\mathrm{IC}<0, \mathrm{CL}>\mathrm{VE} \\
\mathrm{IC}<0, \mathrm{CL}>\mathrm{VE} \\
\mathrm{IC}<0, \mathrm{CL}>\mathrm{VE}\end{array}$ & $\begin{array}{c}\text { Not } \\
\text { viable }\end{array}$ \\
\hline & C & $\begin{aligned} \mathrm{P}_{4} & =0 \\
\mathrm{P}_{7} & =0.554228500 \pm 0.330992359 \\
\mathrm{P}_{10} & =0.0368778035 \pm 0.0032648682 \\
\mathrm{P}_{11} & =0.0150940473 \pm 0.0014453604\end{aligned}$ & $9.1 .10^{-5}$ & 6.23 & $\begin{array}{l}P_{7} \\
P_{10} \\
P_{11}\end{array}$ & $\begin{array}{l}(+) \\
(+) \\
(+)\end{array}$ & $\begin{array}{l}\mathrm{IC}>0, \quad C L<\mathrm{VE} \\
\mathrm{IC}>0, \quad C L<\mathrm{VE} \\
\mathrm{IC}>0, \quad C L<\mathrm{VE}\end{array}$ & Viable \\
\hline \multirow{5}{*}{ VI } & A & $\begin{array}{c}\mathrm{K}_{\mathrm{B}}=-16.3714023 \pm 661.1021023 \\
\mathrm{~K}_{\mathrm{C}}=48.4132846 \pm 2509.3986254 \\
\mathrm{P}_{13}=6.35365882 \pm 135.97712018 \\
\mathrm{P}_{15}=7.14818320 \pm 324.0314528 \\
\mathrm{P}_{16}=2.13263324 \pm 47.39641486 \\
\mathrm{P}_{17}=0.874143654 \pm 19.422821246\end{array}$ & $2.2 .10^{-4}$ & 5.145 & $\begin{array}{l}K_{B} \\
K_{C} \\
P_{13} \\
P_{15} \\
P_{16} \\
P_{17}\end{array}$ & $\begin{array}{l}(-) \\
(+) \\
(+) \\
(+) \\
(+) \\
(+)\end{array}$ & \begin{tabular}{|l|}
$\mathrm{IC}<0, \mathrm{CL}>\mathrm{VE}$ \\
$\mathrm{IC}<0, \mathrm{CL}>\mathrm{VE}$ \\
$\mathrm{IC}<0, \mathrm{CL}>\mathrm{VE}$ \\
$\mathrm{IC}<0, \mathrm{CL}>\mathrm{VE}$ \\
$\mathrm{IC}<0, \mathrm{CL}>\mathrm{VE}$ \\
$\mathrm{IC}<0, \mathrm{CL}>\mathrm{VE}$ \\
\end{tabular} & $\begin{array}{l}\text { Not } \\
\text { viable }\end{array}$ \\
\hline & B & $\begin{array}{c}\mathrm{K}_{\mathrm{B}}=0 \\
\mathrm{~K}_{\mathrm{C}}=53.7394284 \pm 6350.0751416 \\
\mathrm{P}_{13}=3.53653444 \pm 247.34456656 \\
\mathrm{P}_{15}=19.8231433 \pm 1876.7295967 \\
\mathrm{P}_{16}=1.71129670 \pm 50.9810815 \\
P_{17}=0.702039726 \pm 20.910298274\end{array}$ & $2 \cdot 2 \cdot 10^{-4}$ & 5.206 & $\begin{array}{l}K_{C} \\
P_{13} \\
P_{15} \\
P_{16} \\
P_{17}\end{array}$ & $\begin{array}{l}(+) \\
(+) \\
(+) \\
(+) \\
(+)\end{array}$ & $\begin{array}{l}\mathrm{IC}<0, \mathrm{CL}>\mathrm{VE} \\
\mathrm{IC}<0, \mathrm{CL}>\mathrm{VE} \\
\mathrm{IC}<0, \mathrm{CL}>\mathrm{VE} \\
\mathrm{IC}<0, \mathrm{CL}>\mathrm{VE} \\
\mathrm{IC}<0, \mathrm{CL}>\mathrm{VE}\end{array}$ & $\begin{array}{l}\text { Not } \\
\text { viable }\end{array}$ \\
\hline & C & $\begin{aligned} \mathrm{K}_{\mathrm{B}} & =0 \\
\mathrm{P}_{13} & =2.93941739 \pm 18.79975681 \\
\mathrm{P}_{15} & =1.86782613 \pm 10.08702077 \\
\mathrm{P}_{16} & =0.541342090 \pm 5.18514542 \\
\mathrm{P}_{17} & =0.221642448 \pm 2.121511182\end{aligned}$ & $2.2 .10^{-4}$ & 5.26 & $\begin{array}{l}P_{13} \\
P_{15} \\
P_{16} \\
P_{17}\end{array}$ & $\begin{array}{l}(+) \\
(+) \\
(+) \\
(+)\end{array}$ & $\begin{array}{l}\mathrm{IC}<0, \mathrm{CL}>\mathrm{VE} \\
\mathrm{IC}<0, \mathrm{CL}>\mathrm{VE} \\
\mathrm{IC}<0, \mathrm{CL}>\mathrm{VE} \\
\mathrm{IC}<0, \mathrm{CL}>\mathrm{VE}\end{array}$ & $\begin{array}{l}\text { Not } \\
\text { viable }\end{array}$ \\
\hline & D & $\begin{array}{c}\mathrm{K}_{\mathrm{B}}=0 \quad \mathrm{~K}_{\mathrm{C}}=0 \quad \mathrm{P}_{13}=0 \\
\mathrm{P}_{15}=0.610445795 \pm 0.825496865 \\
\mathrm{P}_{16}=0.0357150918 \pm 0.0052744265 \\
\mathrm{P}_{17}=0.0146412833 \pm 0.0023224598\end{array}$ & $2.2 .10^{-4}$ & 5.327 & $\begin{array}{l}P_{15} \\
P_{16} \\
P_{17}\end{array}$ & $\begin{array}{l}(+) \\
(+) \\
(+)\end{array}$ & $\begin{array}{l}\mathrm{IC}<0, \mathrm{CL}>\mathrm{VE} \\
\mathrm{IC}>0, \mathrm{CL}<\mathrm{VE} \\
\mathrm{IC}>0, \mathrm{CL}<\mathrm{VE}\end{array}$ & $\begin{array}{l}\text { Not } \\
\text { viable }\end{array}$ \\
\hline & E & $\begin{array}{l}K_{B}=0 \quad K_{C}=0 \quad P_{13}=0 \quad P_{15}=0 \\
P_{16}=0.0320548839 \pm 0.0012299287 \\
P_{17}=0.0130965076 \pm 0.0007651406\end{array}$ & $2.4 .10^{-4}$ & 5.303 & $\begin{array}{l}P_{16} \\
P_{17}\end{array}$ & $\begin{array}{l}(+) \\
(+)\end{array}$ & $\begin{array}{l}\mathrm{IC}>0, C L<\mathrm{VE} \\
\mathrm{IC}>0, \mathrm{CL}<\mathrm{VE}\end{array}$ & Viable \\
\hline
\end{tabular}

Reaction conditions: $\mathrm{P}_{\mathrm{H} 2}=1.4$ bar, $\mathrm{T}=323 \mathrm{~K}, \mathrm{~W}_{\mathrm{cat}}=0.03 \mathrm{~g}$, stirring rate=800 rpm, $\mathrm{C}_{\mathrm{A}}{ }_{\mathrm{A}}=0.1528 \mathrm{~mol} . \mathrm{L}^{-1}, \mathrm{~S} / \mathrm{Pd}=29385$.

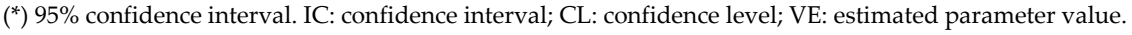

Table 4. Estimated model parameters and model discrimination for $\mathrm{Pd} / \mathrm{Al}_{2} \mathrm{O}_{3}$ 
The heterogeneous model VI-E also produces a good fit of the experimental data but its parameters $\mathrm{K}_{\mathrm{B}}, \mathrm{K}_{\mathrm{C}}, \mathrm{P}_{13}$ and $\mathrm{P}_{15}$ are equal to zero, thus transforming into a pseudo homogeneous reaction rate expression in which the reaction orders in 1-heptyne and hydrogen are positive. This is not in agreement with the observed results, so this model was discarded.

Figure 15 contains values of concentration of 1-heptyne, 1-heptene and n-heptane as a function of time, experimentally (symbols) or theoretically obtained (solid line) with the III$\mathrm{C}$ model. There is an excellent fit.

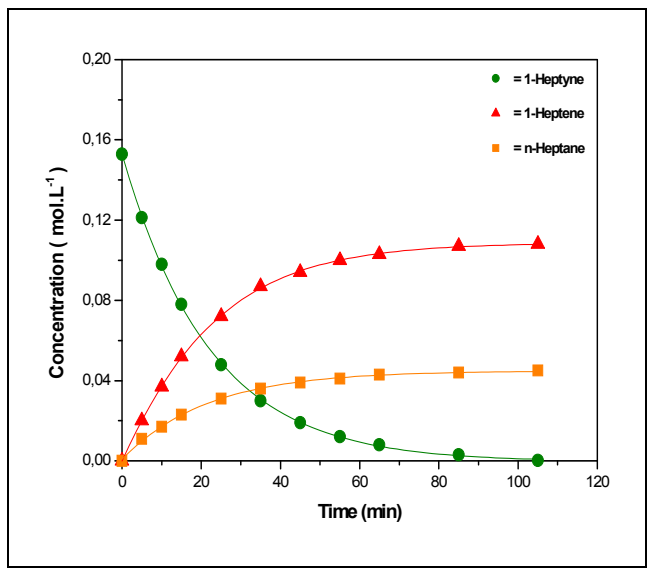

Figure 15. Fit of the experimental data of $\mathrm{C}_{\mathrm{i}}$ as a function of time with model III-C for $\mathrm{Pd} / \mathrm{Al}_{2} \mathrm{O}_{3}$ catalyst. $\mathrm{P}_{\mathrm{H} 2}=1.4$ bar, T=323 K, $800 \mathrm{rpm}, \mathrm{W}_{\text {cat }}=0.03 \mathrm{~g}, \mathrm{~S} / \mathrm{Pd}=29385$.

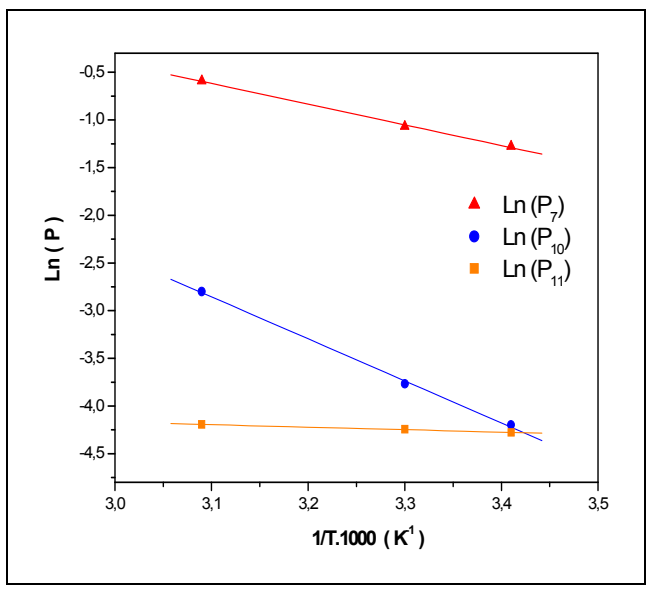

Figure 16. Temperature dependence of parameters $\mathrm{P}_{7}, \mathrm{P}_{10}$ and $\mathrm{P}_{11}$ for $\mathrm{Pd} / \mathrm{Al}_{2} \mathrm{O}_{3}$ catalyst

The same fit with model III-C was repeated with experimental data at other reaction temperatures in the 293-323 K range. In all cases and as a consequence of the fit, parameters 
were obtained with values different from zero in a confidence interval of $95 \%$ and with values of the MSC parameter greater than 4.0. The thermodynamic consistence of parameters $\mathrm{P}_{7}, \mathrm{P}_{10}$ and $\mathrm{P}_{11}$ was evaluated by plotting $\ln \mathrm{P}_{7}, \ln \mathrm{P}_{10}$ and $\ln \mathrm{P}_{11}$ as a function of $1 / \mathrm{T}$. In all cases straight lines were obtained confirming the hypotheses of Arrhenius dependence with respect to temperature (Figure 16).

The slopes of the straight lines obtained correspond to the enthalpies of adsorption of 1heptyne and $\mathrm{H}_{2}$ and the energies of activation of the surface reactions of hydrogenation. Taking into account the definition of the parameters $P_{7}, P_{10}$ and $P_{11}$ (Table 1) the following equations can be obtained:

$$
\mathrm{P}_{7}=\frac{\left(1+\mathrm{K} \cdot \mathrm{K}_{\mathrm{H} 2} \cdot \mathrm{C}_{\mathrm{H} 2}\right) \cdot \mathrm{K}_{\mathrm{A}}}{\sqrt{\mathrm{K}_{\mathrm{H} 2} \cdot \mathrm{C}_{\mathrm{H} 2}}}
$$

Supposing that $1>\mathrm{K} \cdot \mathrm{K}_{\mathrm{H} 2} \cdot \mathrm{C}_{\mathrm{H} 2}$ (this assumption is made for the purpose to estimate some values of the involved constants).

The previous equation is reduced to:

$$
\begin{aligned}
& \mathrm{P}_{7}=\frac{\mathrm{K}_{\mathrm{A}}}{\sqrt{\mathrm{K}_{\mathrm{H} 2} \cdot \mathrm{C}_{\mathrm{H} 2}}}=\frac{\mathrm{A}_{\mathrm{A}}}{\sqrt{\mathrm{A}_{\mathrm{H} 2} \cdot \mathrm{C}_{\mathrm{H} 2}}} \cdot \operatorname{Exp}\left[\frac{-\left(\frac{1}{2} \cdot\left|\Delta \mathrm{H}_{\mathrm{H} 2}\right|-\left|\Delta \mathrm{H}_{\mathrm{A}}\right|\right)}{\mathrm{R} \cdot \mathrm{T}}\right] \\
& \mathrm{P}_{10}=\frac{\mathrm{k}_{1} \cdot \mathrm{K}_{\mathrm{A}} \cdot \mathrm{C}_{\mathrm{S}}^{3}}{\sqrt{\mathrm{K}_{\mathrm{H} 2} \cdot \mathrm{C}_{\mathrm{H} 2}}}=\frac{\mathrm{A}_{1} \cdot \mathrm{A}_{\mathrm{A}} \cdot \mathrm{C}_{\mathrm{S}}^{3}}{\sqrt{\mathrm{A}_{\mathrm{H} 2} \cdot \mathrm{C}_{\mathrm{H} 2}}} \cdot \operatorname{Exp}\left[\frac{-\left(\mathrm{E}_{1}-\left|\Delta \mathrm{H}_{\mathrm{A}}\right|+\frac{1}{2} \cdot\left|\Delta \mathrm{H}_{\mathrm{H} 2}\right|\right)}{\mathrm{R} \cdot \mathrm{T}}\right] \\
& P_{11}=\frac{k_{3} \cdot K_{A} \cdot K \cdot C_{S}^{3}}{\sqrt{K_{H} \cdot C_{H 2}}}=\frac{A_{3} \cdot A_{A} \cdot A \cdot C_{S}^{3}}{\sqrt{A_{H 2} \cdot C_{H 2}}} \cdot \operatorname{Exp}\left[\frac{-\left(E_{3}-\left|\Delta H_{A}\right|+\Delta H+\frac{1}{2} \cdot\left|\Delta H_{H 2}\right|\right)}{R \cdot T}\right]
\end{aligned}
$$

In equations (31), (32) and (33) the enthalpies of adsorption of 1-heptyne and $\mathrm{H}_{2}$ are expressed in absolute values. The values of the respective slopes were calculated as follows:

$$
\begin{gathered}
\frac{\left|\Delta \mathrm{H}_{\mathrm{H} 2}\right|}{2}-\left|\Delta \mathrm{H}_{\mathrm{A}}\right|=18.02 \mathrm{KJ} \mathrm{mol}^{-1} \\
\mathrm{E}_{1}+\frac{\left|\Delta \mathrm{H}_{\mathrm{H} 2}\right|}{2}-\left|\Delta \mathrm{H}_{\mathrm{A}}\right|=36.6 \mathrm{KJ} \mathrm{mol}^{-1} \\
\mathrm{E}_{3}+\Delta \mathrm{H}+\frac{\left|\Delta \mathrm{H}_{\mathrm{H} 2}\right|}{2}-\left|\Delta \mathrm{H}_{\mathrm{A}}\right|=2.18 \mathrm{KJ} \mathrm{mol}^{-1}
\end{gathered}
$$


The enthalpy of $\mathrm{H}_{2}$ adsorption on Pd has been reported in Ref. [35] (-75.31 KJ mol-1), then from equation (34): $\left|\Delta \mathrm{H}_{\mathrm{A}}\right|=19.64 \mathrm{KJ} \mathrm{mol}^{-1}$. Replacing eq. (34) into eq. (35): $\mathrm{E}_{1}=18.58 \mathrm{KJ}$ $\mathrm{mol}^{-1}$. From equations (34) and (36):

$$
\mathrm{E}_{3}+\Delta \mathrm{H}=-15.84 \mathrm{KJ} \mathrm{mol}^{-1}
$$

From the results it can be concluded that:

5. Model III-C that poses the surface chemical reaction as the limiting step is the one that best fits the experimental data. The model also poses the dissociative adsorption of $\mathrm{H}_{2}$ and the competition with 1-heptyne for the active sites. The model presents statistical and thermodynamic consistency.

6. The model enables obtaining directly the values of the enthalpies of adsorption of 1heptyne and the activation energy for the hydrogenation of 1-heptyne to 1-heptene (E1). Neither the calculation of the activation energy for the hydrogenation of 1-heptyne to nheptane $\left(\mathrm{E}_{3}\right)$.

7. The model indicates that 1-heptyne and $\mathrm{H}_{2}$ are the only species adsorbed on the active sites. The enthalpy of adsorption of 1-heptyne over Pd (-19.64 KJ mol-1) is not much different from the value reported by Semagina et al [36] for the hydrogenation of 1hexyne over Pd nanoparticles.

8. Equation (34) shows that the enthalpy of adsorption of hydrogen is higher than that of 1-heptyne over the $\mathrm{Pd} / \mathrm{Al}_{2} \mathrm{O}_{3}$ catalyst. This suggests that there are not thermodynamic limitations for the adsorption of $\mathrm{H}_{2}$. This was confirmed by the tests of hydrogen chemisorptions as $\mathrm{Pd}$ is able to chemisorb an important amount of $\mathrm{H}_{2}$ at room temperature, suggesting that there is not a kinetic impediment as that observed for Ni. Consequently, the dissociative adsorption of hydrogen is fast and then the controlling step is the surface chemical reaction.

9. The value obtained for the activation energy of the hydrogenation reaction of 1-heptyne to 1-heptene (E1) turned out to be quite low $\left(18.58 \mathrm{KJ} \mathrm{mol}^{-1}\right)$. This coincides with the fact that the reaction can proceed at low temperatures.

10. The kinetic modelling of the reactions over the $\mathrm{Ni}$ and $\mathrm{Pd}$ catalysts gives an explanation of the different reactivity of the catalysts. $\mathrm{Pd}$ is more active than $\mathrm{Ni}$ for partial hydrogenation reactions because there is a kinetic limitation for the adsorption of hydrogen on Ni. Hydrogen is more strongly chemisorbed on Pd, so there is a great coverage of the surface by $\mathrm{H}_{2}$, therefore making the surface reaction step as the ratecontrolling one.

\section{Conclusions}

$\mathrm{Pd} / \mathrm{Al}_{2} \mathrm{O}_{3}$ was more active and selective than $\mathrm{Ni} / \mathrm{Al}_{2} \mathrm{O}_{3}$ for the partial hydrogenation of 1heptyne to 1-heptene.

In order to analyze the influence of the different variables (hydrogen partial pressure, initial concentration of 1-heptyne and reaction temperature) on the reaction rate a pseudo 
homogeneous model was proposed based on power law kinetics. Reaction orders for hydrogen and 1-heptyne were obtained as well as the apparent activation energy. For the $\mathrm{Ni} / \mathrm{Al}_{2} \mathrm{O}_{3}$ catalyst, reaction orders of 1.3 in hydrogen and -0.22 in 1-heptyne, and apparent activation energy of $24 \mathrm{KJ} \mathrm{mol}^{-1}$ were obtained. For the $\mathrm{Pd} / \mathrm{Al}_{2} \mathrm{O}_{3}$ catalyst, reaction orders of 2.6 and -1.5 in hydrogen and 1-heptyne, respectively, and apparent activation energy of 18 $\mathrm{KJ} \mathrm{mol}{ }^{-1}$ were obtained.

In order to elucidate the role of $\mathrm{Ni}$ and $\mathrm{Pd}$ on the reaction rate, the kinetic data were fitted with six different heterogeneous LHHW models. The results obtained indicate that for the $\mathrm{Ni} / \mathrm{Al}_{2} \mathrm{O}_{3}$ catalyst the controlling step is the dissociative adsorption of hydrogen over the metal active sites and the reaction rate can be expressed by:

$$
r=\frac{P_{3}}{\left[C_{A}+P_{1} \cdot C_{B}\right]^{2}}
$$

If it is assumed that the adsorption enthalpy of 1-heptene can be considered negligible, a value of $-17.91 \mathrm{KJ} \mathrm{mol}^{-1}$ is obtained for the adsorption enthalpy of 1-heptyne. In the same way, the value of activation energy for the hydrogen adsorption is $22.2 \mathrm{KJ} \mathrm{mol}^{-1}$.

For the $\mathrm{Pd} / \mathrm{Al}_{2} \mathrm{O}_{3}$ catalyst the controlling steps are the surface hydrogenation reactions (1-heptyne to 1-heptene and 1-heptyne to n-heptane). The corresponding reaction rates are:

$$
r_{1}=\frac{P_{10} \cdot C_{A}}{\left[1+P_{7} \cdot C_{A}\right]^{3}} \quad r_{3}=\frac{P_{11} \cdot C_{A}}{\left[1+P_{7} \cdot C_{A}\right]^{3}}
$$

Using a value for the adsorption enthalpy of hydrogen on Pd reported in literature, a value of $-19.64 \mathrm{KJ} \mathrm{mol}^{-1}$ is obtained for the adsorption enthalpy of 1-heptyne $\left(\Delta \mathrm{H}_{\mathrm{A}}\right)$ over Pd. Besides, the value obtained for the activation energy for the hydrogenation reaction of 1heptyne to 1-heptene (E1) was $18.58 \mathrm{KJ} \mathrm{mol}^{-1}$. This coincides with the fact that the reaction can proceed at low temperatures.

The different activity levels of the $\mathrm{Pd} / \mathrm{Al}_{2} \mathrm{O}_{3}$ and $\mathrm{Ni} / \mathrm{Al}_{2} \mathrm{O}_{3}$ catalysts are due to a kinetic limitation for the adsorption of hydrogen on Ni. In the case of Pd this limitation does not exist.

\section{Author details}

M. Juliana Maccarrone, Cecilia Lederhos and Carolina Betti Institute of Catalysis and Petrochemistry Research, INCAPE (CONICET- UNL), Santa Fe, Argentina

Gerardo C. Torres

Departament of Chemical Engineering Reactions, Faculty of Chemical Engineerin, Santa Fe, Argentina 
Juan M. Badano and Mónica Quiroga*

Institute of Catalysis and Petrochemistry Research, INCAPE (CONICET-UNL),

Santa Fe, Argentina

Inorganic Chemistry, Departament of Chemistry, Faculty of Chemical Engineering National

University of Litoral (UNL), Santa Fe, Argentina

Juan Yori

Institute of Catalysis and Petrochemistry Research, INCAPE (CONICET- UNL),

Santa Fe, Argentina

Departament of Chemical Engineering Reactions, Faculty of Chemical Engineering,

Santa Fe, Argentina

\section{Acknowledgement}

The experimental assistance of C. A. Mázzaro and the financial support provided by UNL and CONICET of Argentina are greatly acknowledged.

\section{Notation}

$\alpha$ : order of reaction with respect to 1-heptyne.

$\beta$ : order of reaction with respect to hydrogen.

A: Arrhenius preexponential factor.

AA: preexponential factor of the heat of adsorption of 1-heptyne.

Ав: preexponential factor of the heat of adsorption of 1-heptene.

Анг: preexponential factor of the heat of adsorption of hydrogen.

A1: preexponential factor of the specific reaction rate constant, $\mathrm{k}_{1}$.

$\mathrm{A}_{3}$ : preexponential factor of the specific reaction rate constant, $\mathrm{k}_{3}$.

$\mathrm{C}_{\mathrm{A}^{0}}$ : initial concentration of 1-heptyne $\left(\mathrm{mol} \mathrm{L}^{-1}\right)$.

$\mathrm{C}_{\mathrm{A}}$ : concentration of 1-heptyne $\left(\mathrm{mol} \mathrm{L}^{-1}\right)$.

Св: concentration of 1-heptene $\left(\mathrm{mol} \mathrm{L}^{-1}\right)$.

C: concentration of n-heptane $\left(\mathrm{mol} \mathrm{L}^{-1}\right)$.

$\mathrm{CH}_{\mathrm{H} 2}$ : concentration of hydrogen in the liquid phase $\left(\mathrm{mol} \mathrm{L}^{-1}\right)$.

Cs: concentration of free sites.

EA: apparent activation energy $\left(\mathrm{KJ} \mathrm{mol}^{-1}\right)$.

EH2: activation energy for the hydrogen adsorption $\left(\mathrm{KJ} \mathrm{mol}^{-1}\right)$.

E1: activation energy of the reaction of hydrogenation of 1-heptyne to 1-heptene $\left(\mathrm{KJ} \mathrm{mol}^{-1}\right)$.

E3: activation energy of the reaction of hydrogenation of 1-heptyne to n-heptane $\left(\mathrm{KJ} \mathrm{mol}^{-1}\right)$.

$\Delta \mathrm{H}$ : reaction heat $\left(\mathrm{KJ} \mathrm{mol}^{-1}\right)$

$\left|\Delta \mathrm{H}_{\mathrm{H} 2}\right|$ : absolute value of the enthalpy of hydrogen adsorption $\left(\mathrm{KJ} \mathrm{mol}^{-1}\right)$.

$\left|\Delta \mathrm{H}_{\mathrm{A}}\right|$ : absolute value of the enthalpy of adsorption of 1-heptyne $\left(\mathrm{KJ} \mathrm{mol}^{-1}\right)$.

$\left|\Delta \mathrm{H}_{\mathrm{B}}\right|$ : absolute value of the enthalpy of adsorption of 1-heptene $\left(\mathrm{KJ} \mathrm{mol}^{-1}\right)$.

$\mathrm{k}$ : specific reaction rate constant.

${ }^{*}$ Corresponding Author 
$\mathrm{K}$ : equilibrium constant (equation (6)).

$\mathrm{K}_{\mathrm{A}}$ : adsorption constant for 1-heptyne.

$\mathrm{K}_{\mathrm{B}}$ : adsorption constant for 1-heptene

Kc: adsorption constant for n-heptane

$\mathrm{K}_{\mathrm{H} 2}$ : adsorption constant for hydrogen

$\mathrm{k}_{\mathrm{A}}$ : direct rate specific constant for 1-heptyne adsorption.

$\mathrm{kH}_{2}$ : direct rate specific constant for $\mathrm{H}_{2}$ dissociative adsorption.

$\mathrm{k}_{\mathrm{H} 2}$ : direct rate specific constant for $\mathrm{H}_{2}$ non disociative adsorption.

$\mathrm{k}_{1}$ : direct rate specific constant for 1-heptyne to 1-heptene surface hydrogenation reaction.

$\mathrm{k}_{3}$ : direct rate specific constant for 1-heptyne to n-heptane surface hydrogenation reaction.

$\mathrm{P}_{\mathrm{H} 2}$ : partial pressure of hydrogen (bar).

R: ideal gas universal constant $\left(0.082 \mathrm{~L} \cdot \mathrm{atm} \cdot \mathrm{mol}^{-1} \cdot \mathrm{K}^{-1}\right)$.

r1: rate of step $1\left(\mathrm{~mol} \mathrm{~L}^{-1} \cdot \mathrm{h}^{-1}\right)$.

r3: rate of step $3\left(\mathrm{~mol} \mathrm{~L}^{-1} \cdot \mathrm{h}^{-1}\right)$.

$\mathrm{r}^{0} \mathrm{~A}: 1$-heptyne initial hydrogenation rate $\left(\mathrm{mol} \mathrm{L}^{-1} \cdot \mathrm{h}^{-1}\right)$.

T: absolute temperature $(\mathrm{K})$

t: time.

\section{References}

[1] L'Argentière PC, Cagnola EA, Quiroga ME, Liprandi DA (2002) A palladium tetracoordinated complex as catalyst in the selective hydrogenation of 1-heptyne. Appl. Catal. A: Gen. 226: 253-263.

[2] Lennon D, Marshall R, Webb G, Jackson S D (2000) The effect of hydrogen concentration on propyne hydrogenation over a carbon supported palladium catalyst studied under continuous flow conditions. Stud. Surf. Sci. Catal. 130: 245-250.

[3] Nishimura S. (2001) Handbook of Heterogeneous Catalytic Hydrogenation for Organic Synthesis. John Wiley \& Sons, Inc. Canadá: ISBN 0-47139698-2, pp. 148-169.

[4] Lindlar H, Dubuis R (1966) Palladium catalyst for partial reduction of acetylenes. Org Synth 46: 89-92.

[5] Lederhos CR., L'Argentière PC, Fígoli NS (2005) 1-Heptyne Selective Hydrogenation over Pd Supported Catalyst. Ind. Eng. Chem. Re.s Devel 44: 1752-1756.

[6] Bennett JA, Creamer NJ, Deplanche K, Acaskie LE, Shannon IJ, Wood J (2010) A comparison of $\mathrm{Pd} / \mathrm{Al}_{2} \mathrm{O}_{3}$ and bio-Pd in the hydrogenation of 2-pentyne. J. Chem. Eng. Sc. 65: 282-290.

[7] Sárkány A, Beck A, Horváth A, Révay Zs, Guczi L (2003) Acetylene hydrogenation on sol-derived Pd/SiOz. Appl. Catal. A: Gen. 253: 283-292.

[8] Anderson JA, Mellor JL, Wells RPK (2009) Pd catalysed hexyne hydrogenation modified by Bi and by Pb. J. Catal. 261: 208-216.

[9] Evangelisti C, Panziera N, D'Alessio A, Bertinetti L, Botavina M, Vitulli G (2010) New monodispersed palladium nanoparticles stabilized poly-(N-vinyl-2-pyrrolidone): Preparation, structural study and catalytic properties. J. Catal. 272: 246-252. 
[10] Mastalir A, Király Z (2003) Pd nanoparticles in hydrotalcite: mild and highly selective catalysts for alkyne semihydrogenation. J. Catal. 220: 372-381.

[11] Lederhos CR, Badano JM, Quiroga ME, Coloma-Pascual F, L'Argentière PC. (2010) Influence of $\mathrm{Ni}$ addition to a low-loaded palladium catalyst on the selective hydrogenation of 1-heptyne. Quim. Nova 33(4): 816-820.

[12] Lederhos CR, Maccarrone MJ, Badano JM, Coloma-Pascual F, Yori JC, Quiroga ME (2011) Hept-1-yne partial hydrogenation reaction over supported Pd and W catalysts. Appl. Catal. A: Gen. 396: 170-176.

[13] Alves JA, Bressa SP, Martínez OM, Barreto GF (2007) Kinetic study of the liquid-phase hydrogenation of 1-butyne over a commercial palladium/alumina catalyst. Chem. Eng. J. 125 (3): 131-138.

[14] Crespo-Quesada M, Dykeman RR, Laurenczy G, Dyson PJ, Kiwi-Minsker L (2011) Supported nitrogen-modified Pd nanoparticles for the selective hydrogenation of 1hexyne. J. Catal. 279 (1): 66-74.

[15] Maccarrone MJ, Lederhos C, Badano J, Quiroga ME, Yori J C (2011) Liquid-phase selective hydrogenation of 1-heptyne over $\mathrm{Ni} / \mathrm{Al}_{2} \mathrm{O}_{3}$. Effect of the reaction temperatura. Avances en Ciencias e Ingeniería 2 (2): 59-68.

[16] Boudart M, Hwang HS (1975) Solubility of hydrogen in small particles of palladium J. Catal. 39: 44-52.

[17] Hu S, Chen Y (1998) Partial hydrogenation of benzene: A review. J. Chin. Chem. Eng. 29: 387-396.

[18] L'Argentière P C, Cañón MM, Fígoli NS, Ferrón (1993) AES and XPS Studies of the Influence of $\mathrm{Ni}$ Addition on $\mathrm{Pd} / \mathrm{Al}_{2} \mathrm{O}_{3}$ Catalytic Activity and Sulfur Resistance. J. Appl. Surf. Sci. 68: 41-47.

[19] NIST X-ray Photoelectron Spectroscopy Database NIST Standard Reference Database 20. Version 3.5 (Web Version). National Institute of Standards and Technology. USA. (2007)

[20] Telkar MM, Nadgeri JM, Rode CV, Chaudhari RV (2005) Role of a co-metal in bimetallic $\mathrm{Ni}-\mathrm{Pt}$ catalyst for hydrogenation of $\mathrm{m}$-dinitrobenzene to $\mathrm{m}$-phenylenediamine. Appl. Catal. A: Gen. 295: 23-30.

[21] Juan-Juan J, Roman-Martinez MC, Illan-Gomez MJ (2004) Catalytic activity and characterization of $\mathrm{Ni} / \mathrm{Al}_{2} \mathrm{O}_{3}$ and $\mathrm{NiK} / \mathrm{Al}_{2} \mathrm{O}_{3}$ catalysts for $\mathrm{CO}_{2}$ methane reforming. Appl. Catal. A: Gen. 264: 169-174.

[22] Web Page: www.lasurface.com/accueil/index.php

[23] Wagner CD, Riggs WM, Davis RD, Moulder JF (1978). In Handbook of X-ray Photoelectron Spectroscopy. Muilenberg. G.E., Ed. Perkin-Elmer: Eden Preirie, MN.

[24] Dantas Ramos AL, da Silva Alves P, Aranda DAG, Schmal M (2004) Characterization of carbon supported palladium catalysts: inference of electronic and particle size effects using reaction probes. App. Catal. A: Gen. 277 (1-2): 71-81.

[25] Benitez VM, Querini CA, Fígoli NS, Comelli RA (1999) Skeletal isomerization of 1butene on $\mathrm{WO}_{x} / \gamma-\mathrm{Al}_{2} \mathrm{O}_{3}$. Appl. Catal. A: Gen. 178: 205-218.

[26] Huang S, Zhang C, He H (2008) Complete oxidation of o-xylene over $\mathrm{Pd} / \mathrm{Al}_{2} \mathrm{O}_{3}$ catalyst at low temperature. Catal Today 139: 15-23. 
[27] Salagre P, Fierro JLG, Medina F, Sueiras JE (1996) Characterization of nickel species on several $\gamma$-alumina supported nickel samples. J. Molec. Catal. A: Chem. 106 125-134.

[28] Heracleous E, Lee AF, Wilson K, Lemonidou AA (2005) Investigation of Ni-based alumina-supported catalysts for the oxidative dehydrogenation of ethane to ethylene: structural characterization and reactivity studies. J. Catal. 231: 159-171.

[29] Ferrer V, Moronta A, Sánchez J, Solano R, Bernal S, Finol D (2005) Effect of the reduction temperature on the catalytic activity of pd-supported catalysts. Catal. Today 107: 487-492.

[30] Hou Z, Yokota O, Tanaka T, Yashima T (2003) Characterization of Ca-promoted Ni $/ \gamma$ $\mathrm{Al}_{2} \mathrm{O}_{3}$ catalyst for $\mathrm{CH}_{4}$ reforming with $\mathrm{CO}_{2}$. Appl. Catal. A: Gen 253: 381-387.

[31] Hoffer BW, van Langeveld AD, Janssens JP, Bonne RLC, Lok CM, Moulijn JA (2000) Stability of highly dispersed $\mathrm{Ni} / \mathrm{Al}_{2} \mathrm{O}_{3}$ catalysts: Effects of pretreatment. J. Catal. 192: 432-440.

[32] Li F, Yi X, Fang W (2009) Effect of Organic Nickel Precursor on the Reduction Performance and Hydrogenation Activity of $\mathrm{Ni} / \mathrm{Al}_{2} \mathrm{O}_{3}$ Catalysts. Catal. Let.t 130: 335340.

[33] Mallat T, Baiker A (2000) Selectivity enhancement in heterogeneous catalysis induced by reaction modifiers. App. Catal. A: Gen. 200: 3-22.

[34] Joback KG. Unified Approach to Physical Property Estimation Using Multivariate Statistical Techniques, M.S. Thesis, MIT, Cambridge, MA, (1984).

[35] Sierra Jimenez F, “Algunos aspectos modernos del fenómeno de la adsorción”. 22 (1945) Universidad de Murcia, Servicio de Publicaciones.

[36] Semagina N, Renken A, Kiwi-Minsker L (2007) Monodispersed Pd-nanoparticles on carbon fiber fabrics as structured catalyst for selective hydrogenation. Chem. Eng. Sc. 62 (18-20): 5344-5348. 